\title{
TRADE AGREEMENTS AND ECONOMIC GROWTH
}

\author{
XUEPENG LIU ${ }^{*}$
}

January 10, 2015

\begin{abstract}
This paper studies the growth effects of regional trade agreements (RTAs), taking into account the WTO participation of RTA members. Assuming smaller preference margins of RTAs for WTO members than non-members, I show in a model a stronger growth effect of RTAs for non-WTO members than that for WTO members. Based on a comprehensive set of 270 RTAs and a large panel dataset covering 177 countries over the period of 1960-2007, the regression results show that RTAs promote growth for nonWTO members, while their growth effect is insignificantly different from zero for WTO members. This implies that the complementarity beetween the two approaches of trade liberalization in promoting economic growth is so far limited.
\end{abstract}

[Key words]: regional trade agreements, WTO, economic growth

[JEL Classification]: F1, O4

\footnotetext{
${ }^{*}$ Associate Professor of Economics, Department of Economics and Finance, Kennesaw State University, \#0403, Burruss Bldg \#4, Room 322, 1000 Chastain Rd., Kennesaw, GA 30144, USA; Email: xliu6@kennesaw.edu; Tel: (470)578-6605; Fax: (770)499-3209. I thank Devashish Mitra, Emanuel Ornelas, David J. Richardson, and participants at the Midwest International Trade Meetings at Vanderbilt University and the seminars at Syracuse University and the Federal Reserve Bank of Atlanta for helpful comments, and Jingying Yang for capable research assistance.
} 
"RTAs can foster economic growth and development. But such an outcome is dependent upon various factors, including net trade-creation, an improved regulatory environment, enhanced investment flows and technology transfers. ... A key question is whether they are a building block to non-discrimination or a permanent feature of the trading landscape. Concern has been expressed that some RTAs reflect a defensive necessity aimed at maintaining access to larger markets, locking out competition from other MFN suppliers and locking in investment. If such trends are sustained and not counterbalanced by a successful outcome of the Doha Round, the contribution of an ever-growing number of overlapping RTAs to the economic progress of both parties and non-parties could be negative." (Italics added)

- WTO, Developmental Aspects of the Doha Round of Negotiations

(WT/COMTD/W/143/Rev.2, June 27, 2006)

\section{INTRODUCTION}

It is nearly a consensus among economists that free trade is generally a good thing. Many countries, especially developing countries, regard trade as a means to raise income levels and living standards. ${ }^{1}$ They expect from trade not only static gains, but also dynamic gains related to productivity and technological improvement. Countries have adopted various approaches to liberalize trade. Aside from unilateral trade liberalization and some non-reciprocal agreements such as the General System of Preferences (GSP), freer trade is mainly achieved through reciprocal international trade negotiations, either multilaterally under the GATT/WTO (hereinafter WTO) or bilaterally through regional trade agreements (RTAs). Most of the world trade today is among the WTO members. RTAs, as a major exception to the WTO nondiscrimination rule, have proliferated especially since the 1990s. By 2010, every country except Mongolia is a party to at least one RTA, and the share of intra-RTA trade among the world total trade had increased from 28\% in 1990 to $50.8 \%$ in 2008 (WTO 2011, p64).

Faster economic growth is among the ultimate objectives of trade liberalization of any form including RTAs, as frequently heard from government officials in both developed and developing countries. For example, as reported on the NAFTA by The New York Times (8/13/1992), "President Bush said the agreement ... protects America's place in the world by creating jobs and economic growth. ... Mexico saw the agreement as a symbolic stride in its march away from decades of protectionism and poverty." Recently, many African countries formed RTAs with neighboring countries in hopes of faster economic growth. As a Rwandan government official said, "Integration is our lifeline. ... The Rwandan market is small so all our

\footnotetext{
${ }^{1}$ Some economists, however, doubt the positive trade-growth linkage (see, e.g., Rodriguez and Rodrik 2000).
} 
strategies are closely aligned to becoming a driving force in the regional economic bloc" (Financial Times, 9/22/2009). However, others doubt the positive development effects of RTAs in the region. As a commissioner of the African Union said, "Regional integration has played only a marginal role in most of our development." Although economic development is a major impetus behind regional integration, its effects are yet to be seen. For example, Mexico failed to register fast economic growth after the NAFTA despite the boom in Mexico-U.S. trade. Conversely, as late entrants to RTAs, East Asian countries have been growing faster than the rest of the world. Therefore, examining the growth effects of RTAs is of great relevance to the current debate on regionalism.

In this paper, I study the effect of trade agreements on economic growth. Given the large existing literature on economic growth and trade in general, however, what are the benefits of studying the growth effects of trade agreements in particular? First, most of the existing studies on trade and growth use trade volume (e.g., openness) or trade policy variables (e.g., tariffs), which are usually the results of various approaches to trade liberalization. Studies using these measures cannot disentangle the growth effects of one approach to trade liberalization from others (e.g., the bilateral and multilateral approaches under the RTAs and the WTO, respectively), and are silent on the degree of their complementarity. ${ }^{3}$ Second, there might be something peculiar about trade agreements that benefit their members beyond trade or render the beneficial effects of trade ineffective. The analysis in this paper captures not only the effects of trade agreements on growth through trade, but also their effects through many non-trade channels.

Despite the importance, the growth effects of RTAs do not receive enough attention from researchers. As noticed earlier by Baldwin and Venables (1995, p1614), “The potential growth effects of RIAs [regional integration agreements] often seem to be uppermost in the minds of policy makers, yet they have received relatively little attention in the academic literature." Since then, researchers have made some progress as reviewed in the next section. Existing papers typically use dummy variables for RTAs in cross-country studies and mostly find insignificant growth effects of RTAs. This paper improves upon the existing studies in several ways. First,

\footnotetext{
${ }^{2}$ http://www.bloomberg.com/apps/news?pid=newsarchive\&sid=ab37D5 sN01Y

${ }_{3}^{3}$ Moreover, trade volume is an outcome of many factors. Some of them such as reduction in transportation costs may be completely unrelated to trade policies.
} 
considering the tremendous heterogeneity among RTAs (in terms of the number of partners covered, bloc size, and the degree of liberalization), I use various measures of RTAs that are more precise than indicator variables. Second, previous papers usually study only small subsets of the RTAs formed before the 1990s, while the proliferation of RTAs began in the 1990s. This paper covers a comprehensive set of 270 RTAs reported and not reported to the WTO by 2007. Finally and importantly, previous papers look at the growth effects of the WTO and RTAs separately, while my analysis focuses on how the growth effect of RTAs depends on countries' WTO membership. Despite the intense debate on regionalism versus multilateralism, "This area of research generally does not consider the effects of preferential trade agreements [on growth] as opposed to non-discriminatory trade opening," as noted in the 2011 World Trade Report (WTO 2011, p104). The objective of this paper is to fill this gap. Although this paper does not address directly whether RTAs help or hinder multilateralism, it shows that their complementarity in economic growth is so far limited.

In a theoretical model, the enlargement of a country's free market size resulting from the formation of RTAs affects economic growth through reduced prices of imported intermediate goods. As the main testable hypothesis, the model shows that RTAs are more beneficial to growth for non-WTO members and their growth effects are reduced for WTO members because of the smaller preference margins RTAs can offer beyond MFN tariffs. The model also predicts a postive growth effect of an RTA when the external tariffs applied to countries outside the bloc remain unchanged but the effect can turn weaker (stronger) when the external tariffs increase (decrease) after the RTA comes into force. Using a large panel dataset covering 177 countries over the period of 1960-2007, I find strong empirical support for the main theoretical prediction. RTAs foster economic growth when a country is not a WTO member, and the effect is not significantly different from zero for WTO members. This result is robust to various measures of RTAs and various econometric methods. This is illustrated in Figure 1 by the scatter plots of countries' annual growth rates in 2007 against the share of preferential exports among a country's total exports $\left(E x p s{ }_{-} P\right)$ for non-WTO members (left panel) and WTO members (right 
panel) respectively. The left panel shows a positive association between Expsh_P and growth rates, while the right panel shows a negative relationship between them. ${ }^{4}$

In addition, I find that the above finding holds well for the full-fledged or "deep" RTAs signed under GATT Article XXIV, including free trade areas and customs unions, which are together referred to as free trade agreements (FTAs) in this paper. However, the corresponding estimated coefficeints are indistinguishably different from zero for the partial-scope or "shallow" preferential trade agreements (PTAs) signed under the GATT Enabling Clause. ${ }^{5}$ This is to be expected due to their poor implementation and very limited sector coverage. As described in the same WTO document used for the opening quote, "It is generally accepted that a developmental rationale exists for allowing developing countries to engage in progressive asymmetric liberalization with selected partners. However, if transition periods are too long or too many products are excluded from coverage, potential gains from RTAs in terms of growth and development will be foregone."

The rest of the paper is organized as follows. Section 2 is a review of the literature. In Section 3, I lay out a theoretical model and propose the empirically testable hypothesis. In Section 4, I discuss the empirical strategy and the data. Regression results are reported in Section 5. And I conclude in Section 6.

\section{LITERATURE REVIEW}

There is an extremely large literature on trade and growth. Theoretical predictions can be ambiguous depending on model assumptions. A large empirical literature also produces mixed results, but in general indicates a benign role of trade and openness in economic growth, with the issue of causality still under debate. A thorough review of the literature is beyond the scope of this paper. The discussion here is limited to the studies that relate economic growth to trade agreements, especially RTAs. Relative to studies on trade in general, there are fewer papers on the growth effects of discriminatory trade liberalization. Besides the static welfare effect related to trade creation (diversion) and resource reallocation, RTAs can affect a country's medium-run growth through the accumulation of productive factors such as investment creation and diversion,

\footnotetext{
${ }^{4}$ Expsh_P is calculated by Carpenter and Lendle (2011), who consider preferential only the trade flows with applicable tariffs lower than the corresponding MFN or regular tariffs. More details about these estimates can be found in Section 4.1.

${ }^{5}$ RTAs in this paper include both FTAs and PTAs.
} 
and can also affect a country's long-run growth through their impacts on technology (Baldwin and Venables 1995). ${ }^{6}$ It is difficult to distinguish the static effects from the dynamic effects of RTAs empirically, and this paper does not intend to do so either. Nevertheless, it is still useful to think through theoretically how RTAs can affect economic growth.

In the following, I discuss some additional channels through which trade agreements can affect the economic performance of a country. Some of them have been studied by existing papers. First, the WTO and many RTAs have gone beyond trade in goods to cover trade in services, investment, competition, property rights, migration, and even some political requirements. For example, the liberalization of services sectors under GATS Article V can increase the economic efficiency of a country by reducing not only trade barriers but also many domestic institutional barriers. The alignment of policies on investment and property rights are expected to help long-run growth, although their short-run effects for some countries may be ambiguous. Second, trade agreements may correct international policy externalities and help members to avoid trade wars which would reduce efficiency and dampen economic growth (see, e.g., Grossman and Helpman 1995; and Bagwell and Staiger 1999). Third, trade agreements as a commitment device can help members avoid the time inconsistency problem typically associated with unilateral trade liberalization (see, e.g., Maggi and Rodriguez-Clare 1998; Staiger and Tabellini 1999; and Mitra 2002). Tang and Wei (2009) show that the WTO, as a commitment device, increases its members' investment and economic growth significantly since the Uruguay Round. Related, trade agreements as a commitment device can improve the bargaining position of a government that is weak relative to domestic special interests groups (see, e.g., Limao and Tovar 2011), and help countries with weak institutions to lock-in their reforms which may benefit their long-run economic growth. This is one of the important incentives of many developing countries that seek RTAs with richer nations (e.g., Mexico and the NAFTA; Central and Eastern European countries and the EU). Fourth, RTAs that reduce policy uncertainty and

\footnotetext{
${ }^{6}$ Similarly, Walz (1997) summarizes the dynamic effects of integration on growth as follows: the reallocation effect referring to intra-sectoral and inter-sectoral resource allocation; the redundancy effect referring to the avoidance of duplicative R\&D in different countries in the presence of international technology spillovers; and the scale effect arising from increasing returns to scale associated with either technology spillovers or specialized suppliers in monopolistic competition. The three types of dynamic effects, although labeled slightly differently for broad trade liberalization or restrictions, can be found in earlier papers, such as Rivera-Batiz and Romer (1991). On the FTAtechnology linkage in particular, Dinopoulos and Syropoulos (1996) study theoretically the growth-creating effects of trade blocs through their effects on innovation and technological changes.
} 
macroeconomic instability, and help policy coordination within the bloc can raise long-run growth rates. Cadot, Olarreaga, and Tschopp (2009) provide evidence that RTAs reduce the volatility of trade policy. Economic cooperation and policy coordination within RTAs in areas like public goods provision (i.e., research and training, information sharing, trade facilitation, large scale infrastructure, joint development of institutional rules, and policy harmonization) is especially beneficial to economic growth.

In the theoretical literature, it is not a general conclusion that trade and trade agreements are always growth-friendly. Whether or not trade is good for growth depends on several parameters such as technology diffusion, the source of technological progress, and a country's initial conditions. On RTAs in particular, poorly implemented RTAs waste resources, and highly distortive ones may harm economic development of some members and outsiders when trade and investment diversion dominates trade and investment creation. Even in an overall growthpromoting RTA, some smaller members and those on the periphery may be worse off when firms relocate to the "center" of a bloc. Therefore, the relationship between RTAs and growth is largely an empirical matter.

Among the existing empirical papers on RTAs, most of them use simply RTA dummy variables and examine only several major RTAs prior 1990s (see, e.g., Brada and Mendez 1988; De Melo et al. 1992; Henrekson et al. 1997; Vamvakidis 1999; and Vanhoudt 1999). Berthelon (2004) improves on the previous studies by covering 70 RTAs signed before 2000, considers the size of partners in the RTA measure, and studies the asymmetric growth effects of RTAs for North-North, South-South and North-South agreements. Instead of using a RTA dummy, Badinger (2005) constructs an integration index as the weighted average tariffs and trade costs to measure RTAs, but his analysis is only for EU members. Besides the RTA coverage and measurement issues, these papers provide mixed evidence and do not offer a conclusive view on RTA growth effects.

\section{THEORY}

In this section, I present a model that links FTA preferential tariffs and WTO MFN tariffs to economic growth. In the model, the growth effects of FTAs depend not only on the WTO membership of FTA partners, but also the effects of FTAs on their external tariffs. The technology in this model is assumed to have constant returns to scale, so the benefits of freer 
trade on income and growth are not attained through economies of scale but through the increase in imported inputs due to lower trade barriers.

This model is built on the theory on growth and the political boundary of countries as in Alesina and Spolaore (1997), Alesina et al. (2000), and Spolaore and Wacziarg (2005). In these papers, they study how endogenous country size is determined by trade liberalization and how trade and country size affect economic growth. The theory can be modified to analyze the growth effects of free trade blocs. Instead of studying a country's own size, here I look at the world market size of a country covered by its FTAs. To examine the interaction between regional and multilateral liberalization, I enrich the model by distinguishing the nondiscrimination MFN tariffs applied to WTO members from the tariffs applied to non-members (outsiders), assuming zero tariffs within FTAs. Furthermore, I also discuss the implications when external tariffs of FTA members are endogenously determined.

\subsection{Model structure, assumptions, and equilibrium}

Consider a world in which there is a continuum of firms on the interval $[0, \mathrm{~W}]$ and each firm is located in a different location. Locations (or firms) belong to $N$ different countries with size $\mathrm{S}_{1}, \mathrm{~S}_{2}, \ldots S_{N-1}$, and $S_{N}$ respectively, whose total size is W. A firm in location $i$ produces $y_{i}(t)$ units of a final good $Y$ at time $\mathrm{t}$, according to the following production function.

$$
y_{i}(t)=\mathrm{A}\left(\int_{0}^{W} x_{i j}^{\alpha}(t) d j\right) L_{i}^{1-\alpha}(t)
$$

where $0<\alpha<1 ; x_{i j}(t)$ denotes the amount of intermediate input $j$ used in location $i$ at time $t$ (produced by either home or foreign countries); and $A$ captures the total factor productivity. Each location in a country is assumed to be endowed with one unit of labor $(L=1)$, which is immobile between locations with inelastic supply. Hence, I can drop $L$ from equation $(1)$ and use $y_{i}(t)$ to measure income per capita in terms of final product, which is the same as the income in dollar value because the price of the final product is normalized to one. From now on, I may also omit the time subscript $(\mathrm{t})$ where there is no ambiguity.

At each location $i$, the firm produces a specific input $X_{i}$ using the location-specific capital $K_{i}$ according to the following linear production function.

(2) $X_{i}=K_{i}$ 
where $K_{i}$ denotes the aggregate capital at location $i$. Because the location-specific capital is assumed to be immobile between locations with inelastic supply, equation (2) is also a resource constraint for the supply of intermediate input $i$.

I assume that intermediate inputs can be traded freely with no barriers $(\tau=0)$ within an FTA as an enlarged home market; ${ }^{7}$ while a trade cost of the iceberg type $(0 \leq \tau \leq 1)$ exists between different countries that are not in the same FTA (foreign market). Let $h_{i n^{\prime}}$ denote the unit of input $i$ used at each location within an FTA of country $n^{\prime}$ (home market); and let $f_{i n^{\prime \prime}}$ denote the unit of input $i$ shipped to a foreign location in a non-FTA trading partner $\left(n^{\prime \prime}\right)$, so only $\left(1-\tau_{n^{\prime} n^{\prime \prime}}\right) f_{i n^{\prime \prime}}$ units of input can actually arrive in $n^{\prime \prime}$, where $\tau_{n^{\prime} n^{\prime \prime}}=\tau^{M F N}$ if both $n^{\prime}$ and $n^{\prime \prime}$ are WTO members and $\tau_{n^{\prime} n^{\prime \prime}}=\tau^{O}$ if at least one country is not a WTO member (superscript "o" denotes outsiders). ${ }^{8} \mathrm{I}$ assume $1 \geq \tau^{O} \geq \tau^{M F N} \geq 0$ and the lowest applicable trade barriers always apply. ${ }^{9}$ For simplicity, I assume that $\tau^{M F N}$ is the same for all WTO members; and $\tau^{O}$ is the same for all outsiders.

The intermediate goods markets are assumed to be perfectly competitive. Hence, each unit of input $i$ will be sold at a price equal to its marginal product in both the home market (within FTAs) and the foreign market (outside FTAs), when the price of final goods is normalized to one. The market price of input $i, P_{i}$, can be written as follows.

$$
P_{i}=\alpha A h_{i n^{\prime}}^{\alpha-1}=\alpha A\left(1-\tau_{n^{\prime} n^{\prime \prime}}\right)^{\alpha} f_{i n^{\prime \prime}}^{\alpha-1}
$$

Based on equation (2), I have the following resource constraint for each input $i$ in country $n^{\prime}$ :

$$
K_{i n^{\prime}}=S_{n^{\prime}}^{F T A} h_{i n^{\prime}}^{F T A}+S_{n^{\prime}}^{W T O} f_{i, n^{\prime}}^{W T O}+S_{n^{\prime}}^{O} f_{i, n^{\prime}}^{O}
$$

\footnotetext{
${ }^{7}$ I assume zero internal tariffs for all FTAs for simplicity, keeping in mind that most FTAs have staging periods for tariff reduction. The model can be easily generalized to consider gradual liberalization under FTAs or partial-scope preferential trade arrangements.

${ }^{8}$ I assume that WTO members apply MFN tariffs to the imports from all of the other members but not to nonmembers. Although some WTO members may extend their MFN tariffs to many non-members, the benefits may be limited and are usually subject to uncertainties and the discretion of MFN tariff granting nations. For example, the normal trading relationship granted by the U.S. to China was subject to legislative approval in the U.S. on a yearly basis from 1990 until the late 1990s.

${ }^{9}$ Using the tariff data for 1988-2007 from the UN TRAINS database, supplemented by the data from the WTO IDB, I measure a country's average external tariff in a year by the import weighted average MFN applied tariff. Then I calculate the average tariffs for two groups of countries comprising of non-WTO members and WTO members respectively over 1988-2007, weighted by countries' real GDP; the former is indeed much larger than the latter $\left(\tau^{O}=15 \%\right.$ vs. $\left.\tau^{M F N}=6 \%\right)$.
} 
where $K_{i n^{\prime}}$ is the stock of capital in location $i$ of country $n^{\prime} . S_{n^{\prime}}^{F T A}$ is the market size of the FTAs in which country $n^{\prime}$ is a member and $h_{i n^{\prime}}^{F T A}$ is the unit of input $i$ used in each location within the FTAs. $S_{n^{\prime}}^{W T O}$ is the size of countries that have WTO but no FTA relationships with $n^{\prime}$, and $f_{i, n^{\prime}}^{W T O}$ is the unit of input $i$ shipped to each location in these countries. Equation (4) shows that the resources used to produce input $i$ in country $n^{\prime}$ are allocated among the FTA partners of $n^{\prime}$ (Home, including $n^{\prime}$ itself), other WTO members (but not FTA partners), and non-WTO/FTA members (i.e., $W=S_{n^{\prime}}^{F T A}+S_{n^{\prime}}^{W T O}+S_{n^{\prime}}^{O}$ ). If a country $\left(n^{\prime}\right)$ has no FTA, then the first term of the right side of (4) will be reduced to its own size $\left(S_{n^{\prime}} h_{i n^{\prime}}\right)$. If a country $\left(n^{\prime}\right)$ is not a WTO member, then the second term of the right side of (4) will be zero.

By substituting (3) into (4), I obtain the following two equations.

$$
\begin{aligned}
& h_{i n^{\prime}}=K_{i n^{\prime}} / S \\
& f_{i n^{\prime \prime}}=\left(1-\tau_{n^{\prime} n^{\prime \prime}}\right)^{\alpha /(1-\alpha)}\left[K_{i n^{\prime}} / S\right]
\end{aligned}
$$

where $S=S_{n^{\prime}}^{F T A}+S_{n^{\prime}}^{W T O}\left(1-\tau^{M F N}\right)^{\alpha /(1-\alpha)}+S_{n^{\prime}}^{O}\left(1-\tau^{O}\right)^{\alpha /(1-\alpha)}$. Equations (5) and (6) imply that barriers to trade $(\tau)$ increase the domestic use of an input and reduce international trade. Then, by substituting (5) into (3), I obtain:

$$
P_{i}=\alpha A S^{1-\alpha} K_{i n^{\prime}}^{\alpha-1}
$$

On the consumption side, an individual at each location $i$ is assumed to have the following standard continuous time CRRA intertemporal utility function (or isoelastic utility):

$$
\text { (8) } \quad U_{i}=\int_{0}^{\infty} \frac{c_{i t}^{1-\sigma}-1}{1-\sigma} e^{-\rho t} d t
$$

where $c_{i t}$ denotes a representative individual $i$ 's consumption at time $t$, with $\sigma>0$ as the reciprocal of the constant intertemporal substitution elasticity between any two points in time and $\rho>0$ as a time discount rate. In each location $i$, consumers' total net household assets are identical to the stock of capital $K_{i n^{\prime}}$. Since each unit of capital yields one unit of intermediate input $i$, the net return to capital is equal to the market price of the intermediate input $P_{i}$. Depreciation is assumed away for simplicity. After solving an intertemporal optimization problem, I have the following standard Euler equation for consumption in location $i$ belonging to country $n^{\prime}$ :

$$
\dot{c_{i t}} / c_{i t}=\frac{P_{i}(t)-\rho}{\sigma}=\frac{1}{\sigma}\left(\alpha A S^{1-\alpha} K_{i n^{\prime}}{ }^{\alpha-1}-\rho\right)
$$


where $\dot{c_{l t}}=d c_{i t} / d_{t}$. As in a standard Ramsey model, the steady-state level of capital at each location $i$ of a country $n^{\prime}$ is obtained as the solution of $c_{l t} / c_{i t}=0 .{ }^{10}$

$$
\text { (10) } K_{i n^{\prime}}^{*}=\left(\frac{\alpha A}{\rho}\right)^{1 /(1-\alpha)} S
$$

By substituting (10) into (5) and (6), and using (1), I have the steady state level of output per capita in location $i$ of a country $n^{\prime}$ :

$$
y_{i n^{\prime}}^{*}=\tilde{A} S=\tilde{A}\left[S_{n^{\prime}}^{F T A}+S_{n^{\prime}}^{W T O} \omega^{M F N}+S_{n^{\prime}}^{O} \omega^{O}\right]
$$

where $\tilde{A}=A^{1 /(1-\alpha)}(\alpha / \rho)^{\alpha /(1-\alpha)}, \omega^{M F N}=\left(1-\tau^{M F N}\right)^{\alpha /(1-\alpha)}$ and $\omega^{O}=\left(1-\tau^{O}\right)^{\alpha /(1-\alpha)}$. Because $\omega$ is monotonically decreasing in trade barrier $(\tau), \omega^{M F N}$ and $\omega^{O}$ measure respectively the levels of openness of WTO members and outsiders $\left(1 \geq \omega^{M F N} \geq \omega^{O} \geq 0\right)$.

Using $S_{n^{\prime}}^{O}=W-S_{n^{\prime}}^{F T A}-S_{n^{\prime}}^{W T O}$, I can rewrite (11) as

$$
y_{i n^{\prime}}^{*}=\tilde{A}\left[W \omega^{O}+S_{n^{\prime}}^{F T A}\left(1-\omega^{O}\right)+S_{n^{\prime}}^{W T O}\left(\omega^{M F N}-\omega^{O}\right)\right]
$$

I have so far assumed implicitly that country $n^{\prime}$ is a WTO member. If country $n^{\prime}$ is not a WTO member, then we can rewrite (12) as

$$
y_{i, n^{\prime} \notin W T O}^{*}=\tilde{A}\left[W \omega^{O}+S_{n^{\prime}}^{F T A}\left(1-\omega^{O}\right)\right]
$$

Before performing a comparative statics analysis on how the changes in $\omega, S_{n^{\prime}}^{F T A}$ and $S_{n^{\prime}}^{W T O}$ affect economic growth, we need the following assumptions on the relationship between $S_{n^{\prime}}^{F T A}$ and $S_{n^{\prime}}^{W T O}$.

$$
\begin{aligned}
& \partial S_{n^{\prime}}^{F T A} / \partial S_{n^{\prime}}^{W T O}=0 \\
& \partial S_{n^{\prime}}^{W T O} / \partial S_{n^{\prime}}^{F T A} \in[-1,0]
\end{aligned}
$$

Equation (14) implies that a country's entry into the WTO does not affect the size of its existing FTAs because MFN tariffs are assumed to be higher than (at most equal to) the zero FTA internal tariffs. Equation (15) implies that a new FTA will normally reduce the share of trade under the WTO MFN tariffs because the zero FTA tariffs will replace any corresponding positive MFN tariffs upon the formation of an FTA. If all of the FTA partners were originally WTO members, then $\partial S_{n^{\prime}}^{W T O} / \partial S_{n^{\prime}}^{F T A}=-1$. If all of the FTA partners were originally outside the WTO, then $\partial S_{n^{\prime}}^{W T O} / \partial S_{n^{\prime}}^{F T A}=0$.

\footnotetext{
${ }^{10}$ See, e.g., Barro and Sala-i-Martin (1995, chapter 2) for a detailed derivation.
} 


\subsection{Comparative statics analysis with exogenous external tariffs of FTAs}

For now, I assume that signing an FTA removes the internal trade barriers, but does not affect a country's external tariffs on imports from non-FTA partners. Equations (11)-(15) provide the following comparative statics results:

$$
\begin{aligned}
& \partial y_{i n^{\prime}}^{*} / \partial \omega^{O}=\tilde{A} S_{n^{\prime}}^{O} \geq 0 \\
& \partial y_{i n^{\prime}}^{*} / \partial \omega^{M F N}=\tilde{A} S_{n^{\prime}}^{W T O} \geq 0 \\
& \partial y_{i n^{\prime}}^{*} / \partial S_{n^{\prime}}^{W T O}=\tilde{A}\left(\omega^{M F N}-\omega^{O}\right)>0 \\
& \frac{\partial y_{i n^{\prime}}^{*}}{\partial S_{n^{\prime}}^{F T A}}=\tilde{A}\left[\left(1-\omega^{O}\right)+\left(\omega^{M F N}-\omega^{O}\right) \frac{\partial S_{n^{\prime}}^{W T O}}{\partial S_{n^{\prime}}^{F A}}\right] \in\left[\tilde{A}\left(1-\omega^{M F N}\right), \tilde{A}\left(1-\omega^{O}\right)\right] \\
& \frac{\partial y_{i n^{\prime} \notin W T O}^{*}}{\partial S_{n^{\prime} \notin W T O}^{F T A}}=\tilde{A}\left(1-\omega^{O}\right) \geq \frac{\partial y_{i n^{\prime}}^{*}}{\partial S_{n^{\prime}}^{F T A}}
\end{aligned}
$$

Equations (16) and (17) show that the growth effect of $\omega^{O}\left(\omega^{M F N}\right)$ increases with $S_{n^{\prime}}^{O}$ $\left(S_{n^{\prime}}^{W T O}\right)$ : the larger a country's world market to which $\tau^{O}\left(\tau^{M F N}\right)$ apply, the bigger the effect of $\omega^{O}\left(\omega^{M F N}\right)$ on growth. Equation (18) suggests that the effect of WTO coverage $\left(S_{n^{\prime}}^{W T O}\right)$ on growth depends on $\left(\omega^{M F N}-\omega^{O}\right)$, the degree to which WTO members liberalize trade vis-à-vis outsiders (or the "preference" margin of MFN tariffs over the tariffs applied to imports from outsiders).

Equations (19) and (20), showing the growth effects of FTAs for WTO members and non-WTO members respectively, are the main results of interest. Equation (19) suggests that the growth effects of FTAs for a WTO member also rely on the WTO membership of its FTA partners. If no partner country in a new FTA belongs to the WTO $\left(\partial S_{n^{\prime}}^{W T O} / \partial S_{n^{\prime}}^{F T A}=0\right)$, then the effects of the FTA on growth for a WTO member will be the largest at $\bar{E}=\partial y_{i n^{\prime}}^{*} / \partial S_{n^{\prime}}^{F T A E W T O}=$ $\tilde{A}\left(1-\omega^{O}\right)$, which is the same as if this country is outside the WTO as shown by equation (20). For a WTO member, if all of its FTA partners also belong to the WTO $\left(\partial S_{n^{\prime}}^{W T O} / \partial S_{n^{\prime}}^{F T A}=-1\right)$, then the effects of the FTA on growth will be the smallest at $\underline{E}=\partial y_{i n^{\prime}}^{*} / \partial S_{n^{\prime}}^{F T A E W T O}=$ $\tilde{A}\left(1-\omega^{M F N}\right)$. The differential growth effect between the FTAs that are completely outside the WTO and those that are completely nested inside the WTO can be written as follows:

$$
\bar{E}-\underline{E}=\tilde{A}\left(\omega^{M F N}-\omega^{O}\right)
$$


The above equation also measures the reduced growth effect of FTAs after a country joins the WTO, or the growth effect of the WTO as shown in equation (18). It is a function of the preference margin of the WTO (i.e., $\omega^{M F N}-\omega^{O}$ ). In sum, the model predicts that the WTO and RTAs are substitutable for each other. In the empirical analysis, I adopt two strategies to examine empirically the complementarity between FTAs and the WTO. First, I include in the regressions an interaction term between FTA and WTO measures. Second, I also construct a measure of FTAs between WTO members and another measure of the FTAs not between WTO members, which should have stronger growth effect than the former measure. See Section 4 for a more detailed discussion on the empirical strategies.

In addition, equation (19) also shows that, if the "preference" margin offered by the WTO is small (i.e., $\omega^{M F N} \rightarrow \omega^{O}$ ), then a country's WTO status will not make a big difference. When $\omega^{M F N}=\omega^{O}$, equation (19) for a WTO member is reduced to equation (20) for a non-WTO member. In another special case when there are no trade barriers at all (i.e., $\omega^{M F N}=\omega^{O}=1$ ), FTAs and WTO would be irrelevant to growth.

The following proposition summarizes the main predictions of the above comparative statics analysis:

Proposition The steady state level of output per capita in each location $i$ of a country n' is increasing in the country's level of trade openness $\left(\omega^{M F N}\right.$ and $\left.\omega^{O}\right)$, and the market coverage of its FTAs and the WTO $\left(S_{n^{\prime}}^{\text {FTA }}\right.$ and $\left.S_{n^{\prime}}^{W T O}\right)$. The growth effects of FTAs are stronger for non-WTO members as compared to WTO members.

The above prediction is related to the extent-of-the-market theory, which shows that an increase in openness reduces the importance of domestic income in generating later growth. Alesina and Spolaore (1997), Ades and Glaeser (1999), Alesina et al. (2000), and Spolaore and Wacziarg (2005) argue that access to larger markets helps economic growth especially for small countries; and Alcalá and Ciccone (2003) provide some empirical evidence. Instead of studying the growth effects of a country's domestic economic size and its interaction with openness, in this paper, I look at the growth effects of FTA size and its interaction with WTO membership. 


\subsection{Comparative statics analysis with endogenous external tariffs of FTAs}

FTAs are so far assumed not to affect external tariffs on the imports from non-FTA members. A large literature on endogenous external tariffs suggests that the external tariffs may increase or decrease. Please refer to Freund and Ornelas (2010) among others for reviews of the related papers. I do not intend to incorporate endogenous external tariffs into the model. Relying on theoretical predictions in the existing literature, I only discuss how the endogeneity of external tariffs may affect FTA growth effects, and allow for both positive and negative effects of FTAs on external tariffs, not restricted to a specific mechanism. With endogenous external tariffs of FTAs, $\omega^{M F N}$ and $\omega^{O}$ will be affected by FTAs. For simplicity, I assume that the effects of FTAs on $\omega^{M F N}$ and $\omega^{O}$ are the same (i.e., $\partial \omega^{M F N} / \partial S_{n^{\prime}}^{F T A}=\partial \omega^{O} / \partial S_{n^{\prime}}^{F T A}=\partial \omega / \partial S_{n^{\prime}}^{F T A}$ ). Based on equations (12) and (13), I have:

$$
\begin{aligned}
& \frac{\partial y_{i n^{\prime}}^{*}}{\partial S_{n^{\prime}}^{F T A}}=\tilde{A}\left[\left(1-\omega^{O}\right)+\left(\omega^{M F N}-\omega^{O}\right) \frac{\partial S_{n^{\prime}}^{W T O}}{\partial S_{n^{\prime}}^{F T A}}+\left(W-S_{n^{\prime}}^{F T A}\right) \frac{\partial \omega}{\partial S_{n^{\prime}}^{F T A}}\right] \\
& \frac{\partial y_{i n^{\prime} \notin W T O}^{*}}{\partial S_{n^{\prime} \notin W T O}^{* T A}}=\tilde{A}\left[\left(1-\omega^{O}\right)+W \frac{\partial \omega}{\partial S_{n^{\prime} \notin W T O}^{F T A}}\right]
\end{aligned}
$$

Compared to equations (19) and (20), the above two formulas have an additional term related to the effects of FTAs on external tariffs or openness $(\omega)$. Whether the effects in (22) and (23) are bigger or smaller than those in equations (19) and (20) depends on the sign of $\partial \omega / \partial S_{n^{\prime}}^{F T A}$ or $\partial \omega / \partial S_{n^{\prime} \notin W T O}^{F T A}$. If $\partial \omega / \partial S_{n^{\prime}}^{F T A}>0$ and $\partial \omega / \partial S_{n^{\prime} \notin W T O}^{F T A}>0$, then FTAs reduce external tariffs and this would reinforce the growth effects of FTAs. Conversely, if $\partial \omega / \partial S_{n^{\prime}}^{F T A}<$ 0 and $\partial \omega / \partial S_{n^{\prime} \notin W T O}^{F T A}<0$, then FTAs increase external tariffs and this would reduce the growth effects of FTAs on growth. When the increase in external tariffs is sufficiently large, FTAs overall may reduce growth.

A couple of notes are in order here before the empirical analysis. First, although the theoretical results are driven by market access to inputs, there are many channels through which trade and trade agreements may affect growth (e.g., technology, investment, scale economies, and increased varieties and competition). Empirically, it is difficult to disentangle these effects from each other. I estimate the overall effects of FTAs on growth and consider it a complement rather than a substitute for more detailed work that examines the specific mechanisms by which FTAs affect growth. Therefore, we should allow for a more general economic interpretation of 
the results reported later. Second, higher income levels achieved by countries participating in the WTO or FTAs through reduced trader barriers on inputs is a "level" effect, so what the empirical analysis intends to capture is the economic growth when countries transit from a lower income level to a higher income level after joining the WTO or signing FTAs, or the effects of the WTO and FTAs on the steady-state output. Although this is not a genuine permanent effect on a country's steady state growth rate, this is not really a problem. As Temple (2003) warns, we should not undervalue level effects and it is quite plausible that past and future developments rest entirely on level effects, some large, some small (Obvious Rule \#5). ${ }^{11}$

\section{EMPirical Strategy and DATa}

I test the theoretical predictions using canonical cross-country growth regressions, which can be derived from the Solow growth model (Solow 1956). In a panel data setting, this growth regression should contain some dynamics in lagged output and other controls as follows (see, e.g., Islam 1995).

$$
\ln y_{i, t}=\beta_{1} R T A_{i, t-1}+\beta_{2} R T A_{i, t-1} * W T O_{i, t-1}+\beta_{3} \ln y_{i, t-1}+\mathbf{X}_{\mathrm{i}, \mathrm{t}} \boldsymbol{\gamma}+\mathbf{Z}_{\mathrm{i}, \mathrm{t}} \varphi+\alpha_{i}+\mu_{t}+e_{i, t}
$$

where the first two covariates on the right hand side, the RTA variable and its interaction term with the WTO variable, are the key variables of interest; $y_{i, t}$ and $y_{i, t-1}$ are the current and lagged income per capita; $X_{i, t}$ is a vector containing other classic Solow growth variables including the saving rate (or investment/GDP ratio), population growth rate, etc.; $Z_{i, t}$ contains other traderelated variables including the WTO variable, a GSP measure, etc.; $\alpha_{i}$ and $\mu_{t}$ are country and year fixed effects; and $e_{i, t}$ is an error term. I could also use annual growth rate as the dependent variable, but this is statistically equivalent to specification (24) because the lagged income variable is also included on the right hand side, although the parameter on lagged income has a slightly different interpretation.

\subsection{Measures of trade agreements and empirical strategy}

\footnotetext{
${ }^{11}$ Temple (2003): "In the Solow model, growth can only be maintained by a sequence of level effects, as a constant stream of technical innovations feeds through into higher output. It should not worry us that long-run growth in research-driven models is similarly hard to sustain, or unresponsive to policy. These models will continue to yield level effects that should be central to policy analysis."
} 
The WTO variable used in this paper is a WTO membership dummy. ${ }^{12}$ The preferred WTO membership measure is called de facto membership, which include not only formal WTO members but also non-member participants (NMPs). NMPs include colonies of GATT members, newly-sovereign nations, and provisional applicants to the GATT. The data on NMPs are from Tomz, Goldstein and Rivers (2007), ${ }^{13}$ who show that NMPs are at least as liberalized as formal members in terms of trade promotion. If I classify NMPs as non-members, this will cause a measurement error in WTO membership. Although most of the major trading nations by now have joined the WTO, there are quite a few non-WTO members in earlier years. The share of non-WTO members ranges from 38\% in 1960 to $21 \%$ in 2007 based on the de facto membership.

Measuring RTAs is not straightforward. Most of the previous studies use an RTA dummy indicating if a country is covered by any RTA, ignoring the tremendous heterogeneity in the degree of a country's involvement in RTAs in terms of the size of the trading blocs and the extent of the integration. For instance, Eicher and Henn (2011) show that the trade creation effect is very uneven across different FTAs. In this paper, I use more precise RTA measures. Following Liu and Ornelas (2014), the baseline measure is FTAtradesh, defined as the share of a country's trade with FTA partners among its total trade in a given year. It considers not only the number of RTA partners a country has but also the importance of each partner as measured by trade volume. In this paper, FTAs cover both free trade areas and customs unions signed according to GATT Article XXIV, which I refer to as full-fledged or deep RTAs. I also use an analogous definition PTAtradesh for partial-scope preferential trade agreements (PTAs) signed according to GATT Enabling Clause (shallow RTAs). ${ }^{14}$ Although most agreements are in the FTA category, the trade share of PTAs is nontrivial. The average trade share for PTAs in the sample is 0.05 as compared to 0.12 for FTAs. To construct the trade shares, I carefully consider the dates of the formation of new blocs, of the accession of new members, and of the de-activation of existing blocs. Although

\footnotetext{
${ }^{12}$ Although it cannot measure precisely the likely differential effects of the WTO across countries, it has its own advantage compared to other measures such as MFN tariffs. MFN tariff data are unavailable for non-WTO members, and are missing even for many members before the 1990s. In addition, a WTO membership dummy can capture the effects on growth through not only trade but also non-trade channels. Hence, I use WTO membership as the preferred WTO measure in this paper.

${ }^{13}$ I update the original NMP data (up to 2001) to 2007, assuming that countries had retained their NMP statuses by 2007 unless they joined the WTO after 2001.

${ }^{14}$ There are exceptions; for example, MERCOSUR was signed under the Enabling Clause, but is classified as a free trade area (customs union after 1995).
} 
these measures are not perfect, they can capture more precisely the relative importance of RTA partners than binary RTA variables.

The model predicts that the growth effects of FTAs are stronger for non-WTO members than for WTO members. As indicated in Section 3.2, this can be tested by including in the regressions an interaction term between the WTO membership dummy and FTAtradesh. Another approach is based on equations (19) and (20), which suggest that the growth effects of FTAs depend not only on a country's own WTO membership, but also on the WTO membership of its FTA partners. If a country is not a WTO member or none of its FTA partners belongs to the WTO, then the growth effects of this FTA will be the largest. Conversely, if all of the FTA partners are also WTO members, the growth effects of this FTA will be the smallest because of the small preference margins this FTA can offer. The second approach suggests the following two variables, the sum of which equals FTAtradesh as defined above.

- FTAtradesh_WTO: a WTO member's FTA trade share with other WTO members in a year, which is zero for a non-WTO member;

- FTAtradesh_nWTO: a country's FTA trade share not between the WTO members in a year (i.e., either this country or its FTA partners are outside the WTO).

Although FTAtradesh measures are more precise than the RTA dummy variables as used in other papers, they may overstate the true share of trade conducted on a preferential basis for the following reasons. First, not all of the products traded between FTA partners enjoy preferential treatments because of product exclusions and long staging periods of tariff reduction. ${ }^{15}$ Second, RTA partners' MFN tariff rates on some products may have already been reduced to zero or very low levels so there is not much preference to give. Third, preferential rates under FTAs may not always be utilized because of either small preference margins or high costs related to paper works and rules of origin. For these reasons, I also use two more precise measures of preference margins calculated by Carpenter and Lendle (2011) who consider as preferential only those trade flows for which the applicable tariff is lower than the corresponding

\footnotetext{
${ }^{15}$ Product exclusion is less serious for full-fledged FTAs because GATT Article XXIV requires them to cover "substantially all the trade." Damuri (2009) shows that approximately 7\% of tariff lines in the 15 RTAs between four major economies (U.S., EU, Japan, and Canada) are classified as "products excluded" either temporally or permanently, mostly in agriculture and food sectors.
} 
MFN or regular tariff rates. ${ }^{16}$ They first calculated the share of exports that enjoy preferential tariffs $\left(E X P s{ }_{-} P\right)$ for each exporter. Then they computed the preference margin $(P M)$ as the duties saved from preference (relative to the corresponding MFN or regular tariff rates) divided by a country's total exports. ${ }^{17}$ In the empirical analysis, I also use EXPsh_P or $P M$ to replace FTAtradesh.

Finally, I also include in the analysis a variable for the General System of Preferences (GSPexpsh), which is defined as the share of a country's exports to GSP granting countries among its total exports in a given year. I consider only exports because GSP does not affect directly the imports of GSP receiving countries. Because GSP usually has very limited product coverage, this measure, considering all of the exports to GSP granting countries, is a very rough one. Compared to FTAs and the WTO, GSP is special in that it is non-reciprocal.

\subsection{Choosing other growth determinants}

The growth literature is flooded with a plethora of growth determinants. One challenge in empirical growth research is to identify the relevant regressors. Several approaches have been proposed to select growth variables (see, e.g., Levine and Renelt 1992; Sala-i-Martin 1997). More recently, model averaging techniques have become popular in variable selection as in Brock and Durlauf (2001) and Fernandez, Ley, and Steel (2001). Most studies suggest that initial or lagged income and the share of investment in GDP should be included, but they differ widely on other variables. Since there is no consensus on variable selection, my analysis follows the classic Solow model, augmented with trade related variables as the key variables of interest and many other variables for robustness checks.

The relationship between trade and growth has been studied extensively in the literature. Researchers use different measures of trade policy or trade outcome variables. These variables include but are not limited to trade openness (i.e., (export+import)/GDP), tariff, import penetration, years of open regime, and outward orientation or liberalization. Instead of using

\footnotetext{
${ }^{16}$ Their estimates are based on all of the tariff-line level import and tariff data of the top 20 importers including EU27 and the other 19 largest importers, covering almost 90\% of the world imports in 2008. All of the exporting nations to the top 20 importers are covered. The trade coverage by exporters (as measured by their exports to the top-20 importers divided by their total exports to all of the countries) is also approximately $90 \%$. I use the preference margin estimates for exporters because these estimates cover most of the countries in the world (223 exporters in total).

${ }^{17}$ For exporters outside the WTO such as Russia, their "MFN" tariffs are regular tariffs vis-à-vis preferential tariffs.
} 
these trade volume or trade policy variables, I include various trade agreement measures. I also include the ratio of "nonproductive" government consumption over GDP (net of public spending on education and defense) as an explanatory variable. This ratio is used to capture the effects of the size of government on growth, which is highly relevant to the current debate regarding the role of government versus market in the economy. This ratio, widely used by researchers, is usually found to be negatively correlated with growth (see Barro 1991, among others).

\subsection{Data and sources}

The final dataset used in the regression analysis is large panel covering 177 countries over the period of 1960-2007. The RTA measures are constructed from a bilateral database which covers more than 200 countries. Table 1 has the definitions and descriptive statistics of most of the variables used in the growth regression analysis. Appendix 1 lists the countries covered by the growth regressions with the de facto GATT/WTO entry years in parentheses, and Appendix 2 lists the 270 RTAs used in this paper and seven different data sources. ${ }^{18}$ The import and export data used to construct the RTA trade share measures are from the IMF Direction of Trade Statistics. Data on GDP per capita, investment/GDP ratio, and government consumption/GDP ratio are from the Penn World Table. Legal origin data are drawn from La Porta et al. (1999).

Finally, the GSP data are mainly from the UNCTAD publication: Operation and Effects of the Generalized System of Preferences. I use all of the published reviews 1-10, which offer GSP data for years 1973, 1974, 1975, 1977, 1979, and 1984. In addition, I updated the data to 2008 using another source from the UNCTAD: Generalized System of Preferences List of Beneficiaries [2001, 2005, 2006, and 2008]. ${ }^{19}$ All of the gaps are filled by extending the GSP data backward or forward. ${ }^{20}$ Some checks and changes are made to the original data according to specific government publications on GSP. The graduations or suspensions of some beneficiaries are also considered.

\footnotetext{
${ }^{18}$ Service agreements and accession agreements to existing agreements (e.g., EC) are not counted separately.

${ }^{19}$ UNCTAD/ITCD/TSB/Misc.62 (2001) and UNCTAD/ITCD/TSB/Misc.62/Rev. 1-3 (2005, 2006, 2008).

${ }^{20}$ I extend 1973 GSP back to the original extension date of GSP; use the GSP data in 1975 and 1977 for 1976 and 1978 respectively; extend 1979 and 1984 forward and backward respectively for two years to fill 1980-1983; extend 1984 and 2001 forward and backward respectively for eight years to fill 1985-2000; extend 2001 data forward to 2003; extend 2005 data backward to 2004; and extend 2008 data backward to 2007.
} 


\section{EMPIRICAL EVIDENCE}

The dependent variable in the growth regression is the logarithm of real GDP per capita (i.e., $\log (\mathrm{rGDP} / \mathrm{POP})$ ). To alleviate the potential endogeneity problem, I lag all of the traderelated variables by one year so that they are predetermined in the growth regressions. To control for the unobserved heterogeneity across countries, I allow for country fixed effects in the regressions. I also report the plain OLS regression results, with many additional time-invariant covariates including region dummies, ${ }^{21}$ legal origin dummies, the dummy for the least developed countries (LDCs), ${ }^{22}$ and the dummy for the members of the Organization of Petroleum Exporting Countries (OPEC). These additional covariates are not reported on the result tables to save space.

\subsection{Baseline regression results}

I show first the results from a specification without the interaction term between RTAs and the WTO. The first two columns of Table 2 report the OLS and country fixed effects regression results, using FTAtradesh (deep RTAs only) and de facto WTO membership as the preferred measures. The standard errors for the coefficients are based on White's heteroskedasticity-consistent variance estimates. FTAtradesh is insignificant in both regressions. Probably owing to the substantial heterogeneity among FTAs, it is difficult to find a significant growth effect for all FTAs together. These results, together with the mixed findings in the existing studies as reviewed in section 2, point out the importance of studying the asymmetric effects of trade agreements on growth. In this paper, I investigate in particular the differential effects of RTAs on growth based on countries' WTO membership.

Next, we take into account the WTO membership of RTA participants. Before showing the regression results, I first calculate the simple unconditional average growth rates for different sets of countries grouped based on their WTO and FTA memberships. For non-WTO members, countries with FTAs have an average growth rate nearly 50\% higher than those without FTAs during 1960-2007 (2.75\% versus 1.88\%); while for WTO members, countries with FTAs have an average growth rate only $10 \%$ higher than those without FTAs during the same period of time

\footnotetext{
${ }^{21}$ Africa, Asia, Central America \& Caribbean, Europe, Middle East, North America, Oceania, and South America.

${ }^{22}$ LDCs are defined by the United Nations: http://www.unohrlls.org/en/ldc/related/62/
} 
$(2.22 \%$ versus $2 \%){ }^{23}$ This pattern is consistent with the theoretical prediction and will be further confirmed by the following regression analysis.

Columns (3) and (4) of Table 2 report the OLS and country fixed effects regression results from the regressions with the FTAtradesh*WTO interaction term. The coefficient of FTAtradesh, measuring the growth effect of FTAs for non-WTO members, is positive and significant at the 5\% level. The fixed effects regression results imply that an increase in FTAtradesh by one standard deviation (0.224) can on average lead to approximately $1 \%$ increase in growth rate (i.e., $e^{0.043 * 0.224}-1=1 \%$ ) for non-WTO members. ${ }^{24}$ The coefficient of FTAtradesh*WTO interaction term bears a negative sign and is significant at the $1 \%$ or $5 \%$ level. The sum of the first two coefficients, measuring the growth effects of FTAs for WTO members, is not significantly different from zero as shown by the reported p-values at the bottom of the table. These results tell that FTAs have positive and significant effects on growth only if a country is not a WTO member.

In columns (5) and (6), I include not only FTAtradesh for deep RTAs but also PTAtradesh for shallow RTAs, as well as their interaction terms with the WTO variable. The coefficients for the first two variables are similar to those reported in the previous two columns; while PTAtradesh and its interaction term are highly insignificant. This is to be expected because PTAs have limited sector coverage and are usually poorly implemented. ${ }^{25}$

The extent-of-the-market theory discussed in section 3.2 predicts that an increase in openness should reduce the importance of domestic market size in economic growth. In the last two regressions of Table 2, I add a country size measure and its interaction term with the WTO variable and remove the highly insignificant PTAtradesh related variables. I use the world share of a country's real GDP as a measure for its market size $(r G D P s h) .{ }^{26}$ If the WTO helps to liberalize trade, then its effects on growth should be bigger for smaller countries. The sign

\footnotetext{
${ }^{23}$ These numbers are based on the sample used in the regressions in Table 2.

${ }^{24} \mathrm{We}$ should be cautious in interpreting the significant growth effect of FTAs for non-WTO members. If trade and investment diverting FTAs lower the growth rates of outside countries, then the positive growth effect of these FTAs can be partially driven by their negative growth effect on outsiders. Although the literature is not conclusive on trade diversion, it does not seem to be a major concern as summarized by Freund and Ornelas (2010).

${ }^{25}$ I have also tried adding WTO*GSP and RTA*GSP interactions. Because they are always highly insignificant, I choose not to include them in the regressions.

${ }^{26}$ Previous papers testing the extent-of-market hypothesis usually use initial GDP or population size (POP) to measure market size in cross-sectional growth regressions. In the panel data regressions with country fixed effects, it is not feasible to use initial GDP or POP.
} 
pattern of the first two coefficients reported in columns (7) and (8) supports this view, but these coefficients are not statistically significant at the $10 \%$ level. The coefficients of FTAtradesh and FTAtradesh*WTO stay largely unchanged.

The results are consistent with the finding by Carpenter and Lendle (2011) that the preference margins offered by RTAs relative to MFN tariff rates are small. The share of MFN duty free imports is $52 \%$ in 2008 (excluding EU intra-trade) and over $70 \%$ is the trade at an MFN rate below 5\%; and only $16 \%$ of imports are preferential. WTO (2011) shows that the average applied tariff rate was between $20 \%$ and $30 \%$ in 1947 and dropped to only $4 \%$ across all products and countries in 2009. These facts imply that the benefits of signing RTAs to a WTO member are limited during more recent years.

The insignificant growth effect of FTAs for WTO members may seem to be at odds with the trade-promoting effect of FTAs. Many papers find that countries tend to trade more with their FTA partners than with non-partners, even for WTO members. We should be cautious in interpreting this finding as the evidence for trade creation of FTAs because it can be simply due to that fact that natural trading partners are more likely to form FTAs. Hence, it is crucial to consider the endogeneity of FTAs when estimating their trade effect. In addition, we should consider both trade creation and trade diversion when evaluating the welfare effects of FTAs. Based on a simultaneous equation estimation of FTAs and bilateral trade flows, Magee (2003) finds that trade creation dominates trade diversion but the welfare gain from FTAs is small; and the trade effect of FTAs is sensitive to sample coverage and econometric methods. Baier and Bergstrand (2007, 2009), considering several estimation issues including the endogeneity of RTAs, find a positive and economically large effect of RTAs on trade. Since trade diversion is not considered in their papers, they do not intend to provide welfare implications of FTAs. The empirical literature is not entirely conclusive on the welfare implications of FTAs (see, e.g., Freund and Ornelas, 2010). Even if trade creation dominates trade diversion, faster economic growth is not guaranteed for FTA participants because the trade-growth linkage is still debatable and FTAs may affect growth through many other channels besides trade. Therefore, the insignificant growth effect of FTAs for WTO members is not inconsistent with the existing findings on the trade effect of FTAs. 
In Table 2, other growth determinants have the expected signs: growth is negatively correlated with lagged income as predicted by the income convergence hypothesis. Higher investment/GDP ratio promotes growth, while population growth and government consumption/GDP ratio are inversely related to growth. Table 2 also shows that the WTO variable is positive and significant at the $10 \%$ level only in some OLS regressions, while the coefficient of the GSP variable is always insignificant at the $10 \%$ level.

The weak growth effect of the WTO can be attributed to several factors. First, countries may extend their MFN tariffs to many non-WTO members. For example, an agreements signed at the Hong Kong WTO Ministerial Meetings allows tariff-free access to WTO member markets for $97 \%$ of imported products from the world's 50 least-developed countries by 2008 . Second, it is possible that countries had already made a number of concessions and implemented reforms before joining the WTO to meet the accession requirements. Therefore, an analysis using countries' formal accession dates tends to underestimate the growth effects of the WTO. Third, the likely heterogeneous growth effects of the WTO for different countries may lead to an insignificant overall growth effect. Tang and Wei (2009) find the WTO helps growth only for countries subject to stringent accession requirements since the Uruguay Round. This is also in line with the findings on the trade effects of the WTO in the literature. Rose (2004) finds that WTO members do not trade significantly more than non-members; while Subramanian and Wei (2007) show that the WTO promotes trade only for industrial countries in less protected sectors. Eicher and Henn (2011), using a unified framework, confirm again an overall statistically insignificant trade effect of the WTO. This WTO trade effect "puzzle" was also investigated by other papers. For example, Liu (2009) and Felbermayr and Kohler (2010) show that the WTO helps to generate new trading relationships at the extensive margin, but does not increase the trade among existing trading partners at the intensive margin. ${ }^{27}$

Finally, because of the issues with estimating precisely the growth effect of the WTO as discussed above, this paper focuses on the partial effect of RTAs on growth, rather than the growth effect of the WTO. The negative coefficient of the interaction term in Table 2 also implies that the partial effect of the WTO on growth is smaller for countries that participate

\footnotetext{
${ }^{27}$ For the recent WTO episode (1995-2008), however, Felbermayr and Kohler (2010) find evidence for a tradecreating role of membership at the intensive margin.
} 
actively in regional integration. ${ }^{28}$ No matter if the WTO reduces the preference margins of FTAs or FTAs diminish the trade promoting effect of the WTO, both suggest limited complementarity between the two approaches of trade liberalization.

\subsection{Alternative measures of key variables and other robustness checks}

The previous regressions use the interaction term between FTA and WTO variables to test the main theoretical prediction. I also consider an alternative way to capture their interaction as discussed in Section 4.1. FTAtradesh_WTO and FTAtradesh_nWTO are the FTA trade shares between and not between WTO members respectively. Equations (19) and (20) imply FTAtradesh_nWTO should have stronger growth effects than FTAtradesh_WTO. Panel I in Table 3 reports the results from regressions using these alternative measures, with and without country fixed effects. FTAtradesh_nWTO has a positive and significant growth effect at the 5\% level; while FTAtradesh_WTO is always highly insignificant with a much smaller magnitude. This supports the theoretical prediction and is consistent with the previous results.

Second, I also use the more precise measures of preferential export share $\left(E X P s h \_P\right)$ or preference margins (PM) calculated by Carpenter and Lendle (2011) for 2008 as explained in Section 4.1. Panel II in Table 3 provides the regression results by replacing FTAtradesh with EXPsh_P or PM. Because these measures are available only for one year, I run cross-sectional regressions for year 2007, which is the latest year in the sample. Consistent with the previous findings, the results show again that preferential exports and preference margins are more growth promoting for non-WTO members. The coefficients of the interaction term with the WTO variable are significant at the $1 \%$ or $5 \%$ level. The growth effects of EXPsh_P and $P M$ are actually negative for WTO members, as shown by the sum of the two coefficients. ${ }^{29}$ This is consistent with the pattern shown in Figure 1.

Third, I provide more robustness checks by dropping countries that are unlikely to lie on a regression surface common to the majority of nations, such as microstates, least developed countries, and countries in OPEC (Organization of Petroleum Exporting Countries). The results

\footnotetext{
${ }^{28}$ This is consistent with the finding by Eicher and Henn (2011) that the WTO boosts trade only prior to FTA formation, not afterward.

${ }^{29}$ The null hypothesis that the first two coefficients in regressions (3) and (4) sum to zero is rejected at the 5\% significance level, as shown by the p-values of the F-test reported at the bottom of the table.
} 
are reported in Panel III of Table 3. Regression (5) drops microstates, which are defined as countries with an average real GDP over 1960-2007 less than 10 million USD in constant 2005 price. This removes approximately one third of the countries from the sample. Regression (6) drops the least developed countries according to the UNCTAD definition ${ }^{30}$, and regression (7) drops OPEC countries. In all of these cases, the sign pattern of the FTA and its interaction terms remains the same as before and their coefficients are significant at the 5\% or $10 \%$ level.

Finally, the current specification considers only the differential growth effect of FTAs based on countries' WTO membership, but assumes that the other explanatory variables influence economic growth in the same way regardless of countries' WTO membership. Other variables may also have differential effects when countries are in the WTO as opposed to when they are not. In addition, unobserved characteristics of a country may also change after a country enters the WTO; presumably, this captures the changes in economic policies that occur in order for a country to enter into the WTO as well as the changes in the error term. To allow for a more flexible specification, I split the full sample into two sub-samples according to countries' de facto WTO membership. Using the same specification as in regression (4) of Table 2 with country and year fixed effects, I find that FTAtradesh has a positive and significant coefficient at the $10 \%$ level only in the subsample for non-WTO members $(\beta=0.041)$; for the WTO member subsample, however, the coefficient is much smaller $(\beta=0.009)$ and insignificant at the $10 \%$ level. This is again consistent with the previous finding. ${ }^{31}$ The results are not shown in the paper to save space.

\subsection{Endogeneity of trade agreements}

Endogeneity of trade is a long lasting problem in the trade-growth literature. In this paper, the same problem may exist for trade agreements. I address this issue with both economic and econometric arguments. The results show that FTAtradesh is insignificant by itself in growth regressions (columns (1) and (2), Table 2) but significant after its interaction with the WTO variable is included. This result can be driven by endogeneity of FTAs only if fast growing non-

\footnotetext{
${ }^{30} \mathrm{http}$ //unctad.org/en/pages/aldc/Least\%20Developed\%20Countries/UN-list-of-Least-Developed-Countries.aspx

${ }^{31}$ Investment/GDP ratio and government spending have different growth effects in the two subsamples, while other covariates do not appear to have significantly different growth effects for WTO members and non-members. We do not intend to explain the differential effects of these variables in this paper.
} 
WTO members are more likely to sign FTAs but fast growing WTO members are no more likely to sign FTAs. But this does not sound plausible because the WTO has so far been little more than an "innocent bystander" to regionalism. Therefore, endogeneity cannot explain why FTAs significantly promote growth only if a country is outside the WTO. Even if causation goes the other way, that is, faster growing countries are more likely to join the WTO and FTAs, this is not necessarily an issue. It could be the case that joining an agreement provides an incentive for countries to adopt better economic policies. For example, the accession to the EU requires a country to meet strict convergence criteria, and accession to the WTO also requires a country to meet certain conditions, especially after the Uruguay Round. An application to join the WTO may be simply a demonstration of a government's resolve to change to a more open trade regime (Tang and Wei 2009). Hence, we are just as pleased if this is the case.

Nevertheless, I address the endogeneity problem with formal econometric arguments. To alleviate the endogeneity problem, I have lagged the FTA, WTO and their interaction variables so that they are predetermined in the growth regression. I have also tried including one-year and/or two-year lead variables of the FTA, WTO and their interaction variables to see if changes in FTA and WTO variables are correlated to the income levels in earlier years. None of the lead variables is significant (separately or jointly), suggesting no obvious reverse causality from growth to FTA and WTO membership. The results are not reported but available upon request. In the following, I further address endogeneity using standard two-stage least square (2SLS) and the generalized method of moments (GMM) method for dynamic panel data analysis.

2SLS is a standard method to address endogeneity problems, but its application is limited by the availability of valid instruments. For this reason, I only consider the endogeneity of FTA related variables but take the WTO membership variable as exogenous, given that WTO accessions are based on multilateral negotiations. ${ }^{32}$ Because convergence is not the focus of this paper, I also put aside for now the endogeneity issue of the lagged income variable in 2SLS regressions. The endogeneity of lagged income and WTO variables will be considered later in the GMM regressions. Valid instruments for FTAs should be correlated with FTAtradesh but not with economic growth. Time-invariant geographic variables, which have been used as instruments for trade in cross-country growth regressions as in Frankel and Romer (1999), are

\footnotetext{
${ }^{32}$ Tang and Wei (2009), using a Heckman procedure, do not find evidence of endogeneity of WTO accessions in a growth regression.
} 
inappropriate choices in panel data growth regressions with country fixed effects. Following Liu and Ornelas (2014), I construct the instrument based on the contagion effect of FTA formation. Baldwin (1993) formalizes a domino theory of FTAs in which signing or deepening of an FTA can induce excluded nations to form new FTAs to avoid potential trade diversion. Egger and Larch (2008) and Baldwin and Jaimovich (2010), using spatial econometric methods in a bilateral data setting, find strong evidence for the contagion effect. I also use bilateral data to construct the instrument, but the final contagion measure is at country level to fit into the country*year panel data analysis. I first calculated for each year $t$ the FTAtradesh $h_{i j t}$ for all of the trading partners $(j)$ of a country $(i)$ after excluding country $i$ 's own FTA trade with $j$ to ensure the exogeneity of the instrument. ${ }^{33}$ Contagion $_{i t}$ of country $i$ in year $t$ is calculated as the average FTAtradesh $_{i j t}$ weighted by $1 / \log \left(\right.$ distance $\left._{i j}\right)$, where distance $_{i j}$ is the great circle distance between $i$ and $j$. I use Contagion and Contagion*WTO as the instruments for FTAtradesh and FTAtradesh*WTO (all lagged by one year).

The left panel of Table 4 has the results from a 2SLS regression with country fixed effects and year dummies. The first stage regression results show that Contagion and Contagion*WTO are very strong instruments, both of which are highly significant with very high F-statistics. The second stage regression results provide even stronger support for the main hypothesis. The coefficients of the first two variables are much larger in absolute values as compared to those from regression (4) in Table 2. The sum of the two coefficients is still insignificantly different from zero ( $\mathrm{p}$-value $=0.17$ ).

The panel data growth regressions include the lagged dependent variable as a covariate and contain unobserved panel-level effects. In a dynamic panel data setting, the within-groups transformation leads the transformed lagged dependent variable to be correlated with the transformed error, and hence lead to inconsistency in within estimators. Arellano and Bond (1991) derived a consistent GMM estimator for this model, using lagged level variables as instruments for their first differences. This method has been used to estimate panel data growth regressions as in Caselli, Esquivel, and Lefort (1996). When explanatory variables are highly persistent (e.g., lagged income), lagged levels can be weak instruments for first differences, and the GMM estimator can be severely biased especially in short panels. To improve the precision

\footnotetext{
${ }^{33}$ Because the first stage regressions are exactly identified, I cannot use an over-identification test to verify the exogeneity of the instrument.
} 
and finite sample properties of the estimator, Blundell and Bond (1998) develop a system GMM estimator that uses additional moment conditions in which lagged differences are used as instruments for the level equation in addition to the moment conditions of lagged levels as instruments for the differenced equation. Bond et al. (2001) show that the system GMM estimator provides more reliable estimates when estimating growth regressions. ${ }^{34}$ Hence, I adopt this system estimator in this paper. This method can not only help to correct the bias in the coefficient of the lagged income variable, but also allow for other endogenous explanatory variables. So it can be used to address the potential endogeneity of trade agreement variables. I consider the potential heterogeneity in the error term by providing the asymptotically heteroskedasticity-robust variance estimates. ${ }^{35} \mathrm{I}$ will also provide the test for serial correlation and the Sargan test for over-identification.

The right panel of Table 4 contains the system GMM estimation results. Regression (4) provides the baseline results, using all possible valid lags of lagged income as the GMM type instruments, with all other covariates taken as exogenous. The FTA and FTA*WTO variables bear the same signs as before and are statistically significant, with the magnitude of the coefficients more than doubled in absolute term as compared to that in Table 2. This lends even stronger support to the theoretical prediction. Regression (5) considers both FTA and WTO related variables as endogenous and uses their first two valid lags as GMM type instruments in addition to all valid lags of the lagged income variable. Using further lags of FTA and WTO related variables as instruments offers very similar results. Regression (6) is similar to regression (5) but only takes FTA related variables as endogenous and considers the WTO membership variable as exogenous. Regression (7) is the same as regression (6) except that it uses Contagion and Contagion $* W T O$ as additional standard instruments. The results change little.

The Arellano-Bond test for zero autocorrelation (AC) in first-differenced errors shows that there is a first order serial correlation but no second order serial correlation for all of the GMM regressions in Table 4. This supports the choice of using lagged values as instruments for

\footnotetext{
${ }^{34}$ It is worth acknowledging that the system GMM estimation can also involve weak instruments under certain conditions as shown by Bun and Windmeijer (2010).

${ }^{35}$ The system GMM can be estimated by a one-step or two-step procedure. When the errors are heteroskedastic, simulations suggest that the asymptotic standard errors for the two-step estimators can do poorly in hypothesis testing with typical sample sizes. In these cases, inference based on asymptotic standard errors for the one-step estimators appears to be more reliable (see Arellano and Bond 1991; and Blundell and Bond 1998). Therefore, I adopt the one-step estimation.
} 
the first differences. The Sargan test for over-identification does not reject the null hypothesis that the instruments are valid. ${ }^{36}$ Finally, it is useful to note that the coefficient of the lagged income variable from GMM regressions is very stable ranging from 0.986 to 0.989 in Table 4 , somewhere between the OLS and within estimates reported in Table 2 (approximately 0.99 and 0.96 respectively). As noted by Bond (2002), the true estimate indeed should lie in or near the range between the OLS estimate (upward biased) and within estimate (downward biased). ${ }^{37}$ This fact enhances the reliability of the GMM results, despite the strong assumptions underlying the method. In sum, the GMM results provide even stronger support for the theoretical prediction.

\section{CONCLUDing REMARKS}

Development and economic growth lay at the heart of the current WTO Doha Round negotiations. The rising regionalism has sparked concerns about its development effects, as shown by the opening quote from the WTO. This paper studies the growth effects of RTAs, taking into account the WTO participation of RTA members. I show that RTAs and the WTO do not appear to complement each other in economic growth. Although we do not have to give up one or the other, this does raise some concerns about the motley spaghetti bowls within a multilateral system. Because the multilateral approach of trade liberalization under the WTO is the first best, countries should make some efforts to multilateralize regionalism, as recommended by Baldwin (2006) and the WTO (2011). Non-WTO members may use RTAs as an effective alternative to liberalize trade and prepare for future WTO accessions and multilateral liberalization, provided that these agreements do not lock out competition. For WTO members, we need to understand what the RTAs can possibly accomplish beyond the WTO. In areas where RTAs have the unique capacity to achieve faster and deeper liberalization at no further expense of multilateral rules, RTAs can be a good choice. Otherwise, we should be cautious when countries are forming more and more RTAs, especially PTAs.

\footnotetext{
${ }^{36}$ The distribution of the Sargan test is unknown when the disturbances are heteroskedastic, so the Sargan test is not available if we specify robust standard errors. For non-robust estimation, the Sargan test is heteroskedasticityconsistent only for the two-step GMM. Hence, the Sargan test is based on the two-step procedure. Because this paper covers a long time window (1960-2007), I have many GMM type instruments when using all the valid lags of income per capita as instruments and the p-value for the Sargan test is usually very high. Restricting the GMM type instruments for income per capita to only recent lags can produce significantly smaller p-values without failing the test or overturning the main finding of this paper.

${ }^{37}$ The within estimator is consistent only in fixed $\mathrm{T}$ and large $\mathrm{N}$ panels with all regressors being strictly exogenous.
} 
As a final note, the ex post analysis in this paper seeks to explain the effects of RTAs in the past. The history of RTAs may be a poor guide for the future. Although I find a so far limited contribution of RTAs to the growth of WTO members, RTAs in the future may be guided into the right direction, for which we still need multilateral cooperation under the WTO.

\section{REFERENCES}

Ades, Alberto F., and Edwards L. Glaeser, 1999. "Evidence on growth, increasing returns and the extent of the market." Quarterly Journal of Economics 114(3), 1025-45.

Alcalá, Francisco, and Antonio Ciccone, 2003. "Trade, extent of the market, and economic growth 1960-1996." mimeo, Universitat Pompeu Fabra.

Alesina, Alberto, and Enrico Spolaore, 1997. "On the number and size of nations." Quarterly Journal of Economics 112(4): 1027-56.

Alesina, Alberto, Enrico Spolaore, and Romain Wacziarg, 2000. "Economic integration and political disintegration." American Economic Review 90(5): 1276-96.

Arellano, Manuel, and Stephen Bond, 1991. "Some tests of specification for panel data: Monte Carlo evidence and an application to employment equations." Review of Economic Studies 58: 277-97.

Badinger, Harald, 2005. "Growth effects of economic integration: evidence from the EU member states." Review of World Economy 141(1): 50-78.

Bagwell, Kyle and Robert W. Staiger, 1999. "An economic theory of GATT." American Economic Review 89(1): 215-48.

Baier, Scott, and Jeffrey Bergstrand, 2007. 'Do free trade agreements actually increase members' international trade?" Journal of International Economics 71: 72-95.

Baier, Scott, and Jeffrey Bergstrand, 2009. "Estimating the effects of free trade agreements on trade flows using matching econometrics." Journal of International Economics 77(1): 63-76.

Baldwin, Richard, 1993. "A domino theory of regionalism." NBER Working Paper No. 4465.

Baldwin, Richard E., 2006. "Multilateralising regionalism: spaghetti bowls as building blocs on the path to global free trade." World Economy 29(11): 1451-518.

Baldwin, Richard, and Dany Jaimovich, 2010. "Are free trade agreements contagious?" NBER Working Paper No. 16084.

Baldwin, Richard E., and Anthony J. Venables, 1995. "Regional economic integration.” In: Gene Grossman, and Kenneth Rogoff (eds.) Handbook of International Economics, Vol 3: 1597-644.

Barro, Robert J., 1991. "Economic growth in a cross section of countries." Quarterly Journal of Economics 106(2): 407-43.

Barro, Robert J., and Xavier Sala-i-Martin, 1995. Economic Growth. New York: McGraw Hill.

Berthelon, Matías, 2004. "Growth effects of regional integration agreements." CBP WP 278. http://www.bcentral.cl/estudios/documentos-trabajo/pdf/dtbc278.pdf

Blundell, Richard, and Stephen Bond, 1998. "Initial conditions and moment restrictions in dynamic panel data models." Journal of Econometrics 87(1): 115-43.

Bond, Stephen, Anke Hoeffler, and Jonathan Temple, 2001. "GMM estimation of empirical growth models," Economics Papers 2001-W21, University of Oxford. 
Bond, Stephen, 2002. "Dynamic panel data models: a guide to micro data methods and practice." Working Paper 09/02. Institute for Fiscal Studies. London.

Brada, Josef C., and Jose A. Mendez, 1988. "An estimate of the dynamic effects of economic integration." Review of Economics and Statistics 70(1): 163-68.

Brock, William A., and Steven N. Durlauf, 2001. "What have we learned from a decade of empirical research on growth? Growth Empirics and Reality" World Bank Economic Review 15(2): 229-71.

Bun, Maurice J. G., and Frank Windmeijer, 2010. "The weak instrument problem of the system GMM estimator in dynamic panel data models." The Econometrics Journal 13(1): 95-126.

Cadot, Olivier, Marcelo Olarreaga, and Jeanne Tschopp, 2009. "Does regionalism reduce the volatility of trade policy?" Available at: http://works.bepress.com/ocadot/17

Carpenter, Theresa, and Andreas Lendle, 2011. "How preferential is world trade." CTEI Working Paper 2010-32. http://voxeu.org/index.php?q=node/6279

Caselli, Francesco, Gerardo Esquivel, and Fernando Lefort, 1996. "Reopening the convergence debate: a new look at cross country growth empirics." Journal of Economic Growth 1(3): 363-89.

Damuri, Yose R., 2009. "How preferential are preferential trade agreements? Analysis of product exclusions in PTAs.” NCCR Working Paper No 2009/30.

De Melo, Jaime, Claudio Montenegro, and Arvind Panagariya, 1992. "Regional integration, old and new." World Bank Policy Research Working Paper Series 985.

Dinopoulos, Elias, and Constantinos Syropoulos, 1996. "Growth-creating trading blocs." Canadian Journal of Economics 29(s1): 371-5.

Durlauf, Steven N., Paul A. Johnson, and Jonathan Temple, 2005. "Growth econometrics.” In: Philippe Aghion and Steven N. Durlauf (eds.) Handbook of Economic Growth, North-Holland.

Egger, Peter, and Mario Larch, 2008. "Interdependent preferential trade agreement memberships: an empirical analysis.” Journal of International Economics 76(2): 384-99.

Eicher, Theo S., and Christian Henn, 2011. "In search of WTO trade effects: Preferential trade agreements promote trade strongly, but unevenly." Journal of International Economics 83: 13753.

Felbermayr, Gabriel J., and Wilhelm Kohler, 2010. "Modelling the extensive margin of world trade: New evidence on GATT and WTO membership." The World Economy 33(11): 1430-69.

Fernandez, Carmen, Eduardo Ley, and Mark Steel, 2001. "Model uncertainty in cross-country growth regressions." Journal of Applied Econometrics 16(5): 563-76.

Frankel, Jeffrey A., and David Romer, 1999. "Does trade cause growth?" American Economic Review 89: 379-99.

Freund, Caroline, and Emanuel Ornelas, 2010. "Regional trade agreements." Annual Review of Economics 2: 139-66.

Grossman, Gene M., and Elhanan Helpman, 1995. "Trade wars and trade talks.” Journal of Political Economy 103(4): 675-708.

Henrekson, Magnus, Johan Torstensson, and Rasha Torstensson, 1997. "Growth effects of European integration." European Economic Review 41(8): 1537-57.

Islam, Nazrul, 1995. "Growth empirics: A panel data approach." Quarterly Journal of Economics 110(4): 1127-70.

La Porta, Raphael, Franscico Lopez-De-Silanes, Andrei Shleifer, and Robert Vishny, 1999. "The quality of government." Journal of Law, Economics and Organization 15: 222-79. 
Levine, Ross, and David Renelt, 1992. "A sensitivity analysis of cross-country growth regressions." American Economic Review 82(4): 942-63.

Limao, Nuno, and Patricia Tovar, 2011. "Policy choice: theory and evidence from commitment via international trade agreements." Journal of International Economics 85(2): 186-205.

Liu, Xuepeng, 2009. "The GATT/WTO promotes trade strongly: Sample selection and model specification." Review of International Economics 17(3): 428-46.

Liu, Xuepeng, and Emanuel Ornelas, 2014. "Free trade agreements and the consolidation of democracy." American Economic Journal: Macroeconomics 6(2): 29-70.

Magee, Christopher, 2003. "Endogenous preferential trade agreements: an empirical analysis." Contributions to Economic Analysis \& Policy 2(1), Article 15.

Maggi, Giovanni, and Andres Rodriguez-Clare, 1998. "The value of trade agreements in the presence of political pressures." Journal of Political Economy 106(3): 574-601.

Mitra, Devashish, 2002. "Endogenous political organization and the value of trade agreements," Journal of International Economics 57(2): 473-85.

Rivera-Batiz, Luis A., and Paul M. Romer, 1991. "International trade with endogenous technological change.” European Economic Review 35(4): 971-1001.

Rodriguez, Francisco, and Dani Rodrik, 2000. "Trade policy and economic growth: a skeptics guide to the cross-national evidence." In: Ben Bernanke, and Kenneth Rogoff (eds.) NBER Macroeconomics Annual, Cambridge (MA): MIT Press.

Rose, Andrew, 2004. "Do we really know that the WTO increases trade?" American Economic Review 94(1): 98-114.

Sala-i-Martin, Xavier, 1997. "I just ran 2 million regressions." American Economic Review 87(2): 178-83.

Solow, Robert, 1956. "A contribution to the theory of economic growth." Quarterly Journal of Economics 70(1): 65-94.

Spolaore, Enrico, and Romain Wacziarg, 2005. "Borders and growth." Journal of Economic Growth 10(4): 331-86.

Staiger, Robert, and Guido Tabellini, 1999. "Do GATT rules help governments make domestic commitments?" Economics and Politics 11(2): 109-44.

Subramanian, Arvind, and Shang-Jin Wei, 2007. "The WTO promotes trade, strongly but unevenly." Journal of International Economics 72(1): 151-75.

Tang, Man-Keung, and Shang-Jin Wei, 2009. "The value of making commitments externally: Evidence from WTO accessions." Journal of International Economics 78(2): 216-29.

Temple, Jonathan, 2003. "The long-run implications of growth theories." Journal of Economic Surveys 17(3): 497-510.

Tomz, Michael, Judith L. Goldstein, and Douglas Rivers, 2007. "Do we really know that the WTO increases trade? Comment." American Economic Review 97(5): 2005-18.

Vamvakidis, Athanasios, 1999. "Regional trade agreements or broad liberalization: which path leads to faster growth?" IMF Staff Papers 46(1): 42-68.

Vanhoudt, Patrick, 1999. "Did the European unification induce economic growth? In search of scale effects and persistent changes." Review of World Economics 135(2): 193-220.

Walz, UI, 1997. "Dynamic effects of economic integration: a survey." Open Economies Review 8(3): 309-26.

WTO, 2011. "The WTO and preferential trade agreements and the WTO: from co-existence to coherence." World Trade Report. Geneva, Switzerland. 
Figure 1: Scatter plots of growth rates against share of preferential exports $\left(E X P s h \_P\right)$
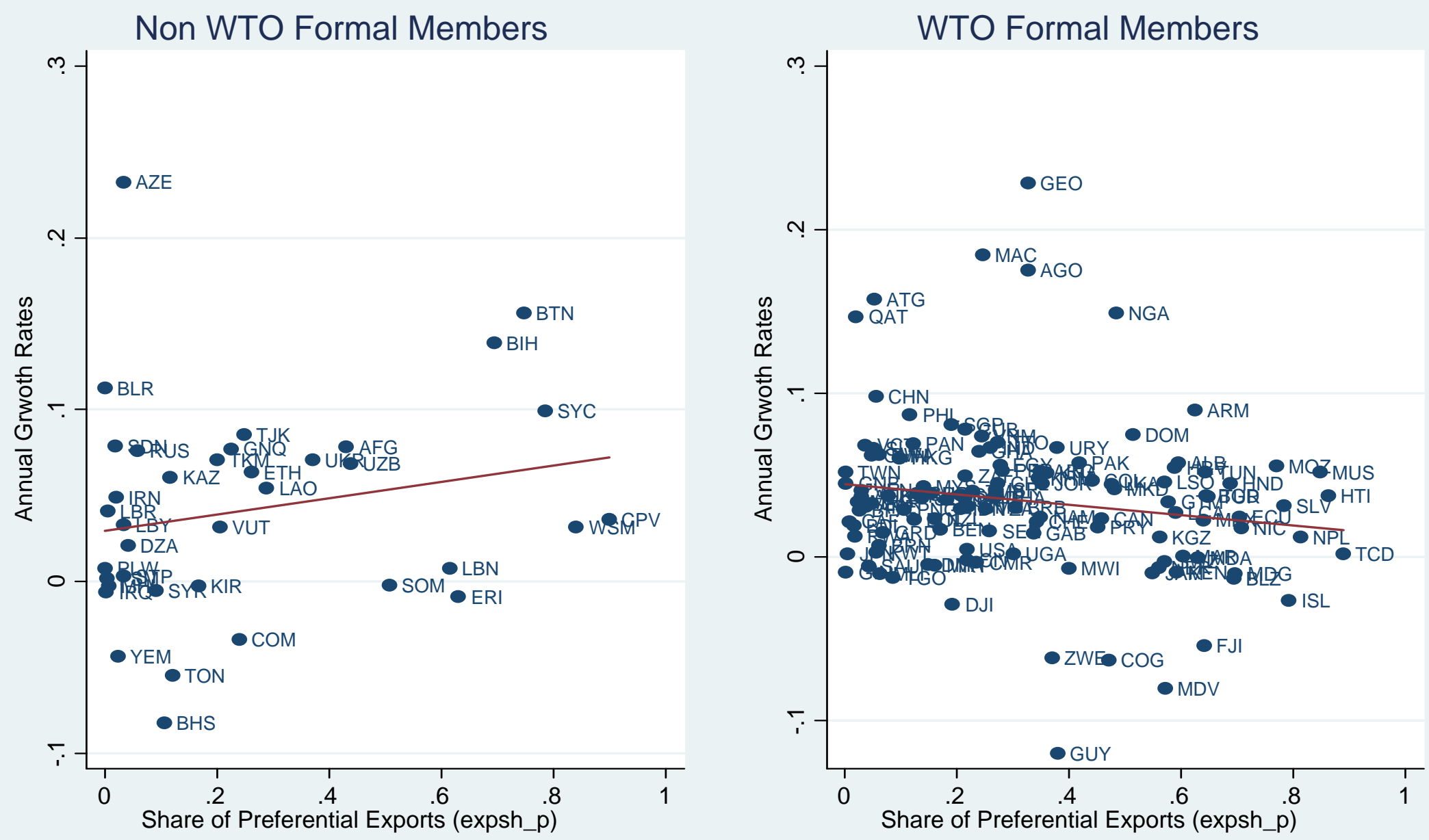

Notes: The annual growth rates in 2007 are based on the constant price GDP/capita data (chain series) from PWT. The calculated shares of preferential exports $(E X P s h P)$ are from Carpenter and Lendle (2011). Countries are labeled by their ISO codes. Both figures use de facto WTO membership. Using formal membership produces nearly identical diagrams. Among the 157 countries with data on both GDP/capita growth rates and EXPsh_P, only Bermuda is classified as a de facto WTO member but not a formal member in 2007. 
Table 1: Descriptive statistics

\begin{tabular}{|c|c|c|c|c|c|c|}
\hline Variable & Definitions & Obs. & Mean & S.D. & Min & Max \\
\hline $\log (\mathrm{rGDP} / \mathrm{POP})$ & Log(real GDP per capita) & 6741 & 8.472 & 1.163 & 5.032 & 11.624 \\
\hline $\log ($ rGDP/POP $) 11$ & Lagged log(rGDP/POP) & 6741 & 8.454 & 1.159 & 5.032 & 11.624 \\
\hline WTO_11 & Lagged de facto WTO Member & 6741 & 0.758 & 0.428 & 0 & 1 \\
\hline FTAtradesh_11 & Lagged FTA trade share & 6741 & 0.118 & 0.224 & 0 & 1 \\
\hline PTAtradesh_11 & Lagged PTA trade share & 6741 & 0.053 & 0.117 & 0 & 0.798 \\
\hline FTAtradesh_nWTO_11 & Lagged FTA trade share not between WTO members & 6741 & 0.018 & 0.081 & 0 & 0.818 \\
\hline FTAtradesh_WTO_11 & Lagged FTA trade share between WTO members & 6741 & 0.100 & 0.215 & 0 & 1 \\
\hline rGDPsh_11 & Lagged World share of real GDP & 6741 & 0.007 & 0.023 & 0 & 0.322 \\
\hline GSPexpsh_11 & Lagged share of exports to GSP granting countries & 6741 & 0.385 & 0.344 & 0 & 1 \\
\hline $\log (\mathrm{I} / \mathrm{GDP})$ & Log(Investment/GDP) & 6741 & 2.797 & 0.722 & -0.201 & 4.633 \\
\hline $\log (\mathrm{G} / \mathrm{GDP})$ & Log(Government Spending/GDP) & 6741 & 2.798 & 0.536 & 0.098 & 4.467 \\
\hline $\log ($ gr_POP $)$ & Log(Population growth rate) & 6741 & -4.147 & 0.916 & -13.721 & -0.926 \\
\hline EXPsh_P & Share of exports that enjoy preferential tariffs & 143 & 0.310 & 0.253 & 0 & 0.899 \\
\hline PM & Preference margins & 143 & 0.347 & 0.470 & 0 & 0.241 \\
\hline
\end{tabular}

Notes: Most of the descriptive statistics are based on the sample of 6741 observations used in Table 2, except the last two variables at the bottom which are based on the sample used in Panel II of Table 3. "X_11" refers to the lagged value of a variable X by one year. 
Table 2: OLS and country fixed effects (FE) regression results

\begin{tabular}{|c|c|c|c|c|c|c|c|c|}
\hline & $(1)$ & $(2)$ & (3) & $(4)$ & $(5)$ & $(6)$ & $(7)$ & $(8)$ \\
\hline & OLS & $\mathrm{FE}$ & OLS & $\mathrm{FE}$ & OLS & $\mathrm{FE}$ & OLS & $\mathrm{FE}$ \\
\hline FTAtradesh_11 & $\begin{array}{l}0.001 \\
(0.005)\end{array}$ & $\begin{array}{l}0.008 \\
(0.007)\end{array}$ & $\begin{array}{l}0.027 * * \\
(0.012)\end{array}$ & $\begin{array}{l}0.043 * * \\
(0.019)\end{array}$ & $\begin{array}{l}0.028 * * \\
(0.012)\end{array}$ & $\begin{array}{l}0.045 * * \\
(0.019)\end{array}$ & $\begin{array}{l}0.030 * * \\
(0.012)\end{array}$ & $\begin{array}{l}0.043 * * \\
(0.019)\end{array}$ \\
\hline FTAtradesh_11 * WTO_l1 & & & $\begin{array}{l}-0.032 * * * \\
(0.012)\end{array}$ & $\begin{array}{l}-0.041 * * \\
(0.018)\end{array}$ & $\begin{array}{l}-0.032 * * * \\
(0.012)\end{array}$ & $\begin{array}{l}-0.040 * * \\
(0.018)\end{array}$ & $\begin{array}{l}-0.035 * * * \\
(0.013)\end{array}$ & $\begin{array}{l}-0.040 * * \\
(0.018)\end{array}$ \\
\hline PTAtradesh_11 & & & & & $\begin{array}{l}0.007 \\
(0.018)\end{array}$ & $\begin{array}{l}0.005 \\
(0.023)\end{array}$ & & \\
\hline PTAtradesh_11*WTO_11 & & & & & $\begin{array}{l}-0.006 \\
(0.017)\end{array}$ & $\begin{array}{l}0.011 \\
(0.022)\end{array}$ & & \\
\hline rGDPsh_11 & & & & & & & $\begin{array}{l}0.218 \\
(0.145)\end{array}$ & $\begin{array}{l}0.539 \\
(0.530)\end{array}$ \\
\hline rGDPsh_11 *WTO_11 & & & & & & & $\begin{array}{l}-0.225 \\
(0.140)\end{array}$ & $\begin{array}{l}-0.148 \\
(0.219)\end{array}$ \\
\hline $\log (\mathrm{rGDP} / \mathrm{POP}) \_11$ & $\begin{array}{l}0.994 * * * \\
(0.002)\end{array}$ & $\begin{array}{l}0.962 * * * \\
(0.006)\end{array}$ & $\begin{array}{l}0.994 * * * \\
(0.002)\end{array}$ & $\begin{array}{l}0.962 * * * \\
(0.006)\end{array}$ & $\begin{array}{l}0.994 * * * \\
(0.002)\end{array}$ & $\begin{array}{l}0.961 * * * \\
(0.006)\end{array}$ & $\begin{array}{l}0.994 * * * \\
(0.002)\end{array}$ & $\begin{array}{l}0.961 * * * \\
(0.005)\end{array}$ \\
\hline $\log (\mathrm{I} / \mathrm{GDP})$ & $\begin{array}{l}0.014 * * * \\
(0.003)\end{array}$ & $\begin{array}{l}0.017 * * \\
(0.008)\end{array}$ & $\begin{array}{l}0.015 * * * \\
(0.003)\end{array}$ & $\begin{array}{l}0.017 * * \\
(0.008)\end{array}$ & $\begin{array}{l}0.015 * * * \\
(0.003)\end{array}$ & $\begin{array}{l}0.017 * * \\
(0.008)\end{array}$ & $\begin{array}{l}0.014 * * * \\
(0.003)\end{array}$ & $\begin{array}{l}0.016 * * \\
(0.008)\end{array}$ \\
\hline $\log (\mathrm{G} / \mathrm{GDP})$ & $\begin{array}{l}-0.007 * * * \\
(0.002)\end{array}$ & $\begin{array}{l}-0.028^{* * *} \\
(0.007)\end{array}$ & $\begin{array}{l}-0.008 * * * \\
(0.002)\end{array}$ & $\begin{array}{l}-0.028 * * * \\
(0.007)\end{array}$ & $\begin{array}{l}-0.008 * * * \\
(0.002)\end{array}$ & $\begin{array}{l}-0.028^{* * *} \\
(0.007)\end{array}$ & $\begin{array}{l}-0.008 * * * \\
(0.002)\end{array}$ & $\begin{array}{l}-0.029 * * * \\
(0.006)\end{array}$ \\
\hline log(gr_POP) & $\begin{array}{l}-0.004 * * \\
(0.002)\end{array}$ & $\begin{array}{l}-0.004 * * \\
(0.002)\end{array}$ & $\begin{array}{l}-0.004 * * \\
(0.002)\end{array}$ & $\begin{array}{l}-0.004 * * \\
(0.002)\end{array}$ & $\begin{array}{l}-0.004 * * \\
(0.002)\end{array}$ & $\begin{array}{l}-0.004 * * \\
(0.002)\end{array}$ & $\begin{array}{l}-0.004 * * \\
(0.002)\end{array}$ & $\begin{array}{l}-0.004 * * \\
(0.002)\end{array}$ \\
\hline WTO_11 & $\begin{array}{l}0.004 \\
(0.003)\end{array}$ & $\begin{array}{l}-0.002 \\
(0.004)\end{array}$ & $\begin{array}{l}0.005^{*} \\
(0.003)\end{array}$ & $\begin{array}{l}0.001 \\
(0.004)\end{array}$ & $\begin{array}{l}0.006^{*} \\
(0.003)\end{array}$ & $\begin{array}{l}-0.000 \\
(0.004)\end{array}$ & $\begin{array}{l}0.006^{*} \\
(0.003)\end{array}$ & $\begin{array}{l}0.000 \\
(0.004)\end{array}$ \\
\hline GSPexpsh_11 & $\begin{array}{l}0.006 \\
(0.005)\end{array}$ & $\begin{array}{l}0.008 \\
(0.006)\end{array}$ & $\begin{array}{l}0.005 \\
(0.005)\end{array}$ & $\begin{array}{l}0.007 \\
(0.006)\end{array}$ & $\begin{array}{l}0.005 \\
(0.005)\end{array}$ & $\begin{array}{l}0.007 \\
(0.006)\end{array}$ & $\begin{array}{l}0.005 \\
(0.005)\end{array}$ & $\begin{array}{l}0.006 \\
(0.007)\end{array}$ \\
\hline Other covariates & Yes & & Yes & & Yes & & Yes & \\
\hline R-squared & 0.997 & 0.961 & 0.997 & 0.961 & 0.997 & 0.961 & 0.997 & 0.961 \\
\hline $\begin{array}{l}\text { Observations } \\
\text { F-test for } \mathrm{b} 1+\mathrm{b} 2=0[\mathrm{p} \text {-value }]\end{array}$ & 6,741 & 6,741 & $\begin{array}{l}6,741 \\
{[0.368]}\end{array}$ & $\begin{array}{l}6,741 \\
{[0.815]}\end{array}$ & $\begin{array}{l}6,741 \\
{[0.414]}\end{array}$ & $\begin{array}{l}6,741 \\
{[0.585]}\end{array}$ & $\begin{array}{l}6,741 \\
{[0.323]}\end{array}$ & $\begin{array}{l}6,741 \\
{[0.619]}\end{array}$ \\
\hline
\end{tabular}

Notes: The dependent variable is $\log (r G D P / P O P)$. "X_11" refers to the lagged value of a variable $\mathrm{X}$ by one year. Year dummies are included in all of the regressions. "Other covariates" include the following time-invariant variables: region dummies, legal origin dummies, a dummy for least developed countries, and a dummy for OPEC countries. These variables are not shown on the table to save space. The test for $b 1+b 2=0$ [p-value] provides the p-values for the test of the H0 that the first two coefficients sum to zero. Robust standard errors in parentheses. $* * * \mathrm{p}<0.01, * * \mathrm{p}<0.05,{ }^{*} \mathrm{p}<0.1$. 
Table 3: Robustness checks

\begin{tabular}{|c|c|c|c|c|c|c|c|}
\hline & \multicolumn{2}{|c|}{ Panel I } & \multicolumn{2}{|l|}{ Panel II } & \multicolumn{3}{|c|}{ Panel III } \\
\hline & (1) & (2) & (3) & (4) & (5) Drop & (6) & (7) \\
\hline & OLS & FE & Cross Section & Cross Section & Micro states & Drop LDC & Drop OPEC \\
\hline FTAtradesh_WTO_11 & $\begin{array}{l}-0.005 \\
(0.005)\end{array}$ & $\begin{array}{l}0.000 \\
(0.007)\end{array}$ & & & & & \\
\hline FTAtradesh_nWTO_11 & $\begin{array}{l}0.024 * * \\
(0.011)\end{array}$ & $\begin{array}{l}0.045 * * \\
(0.019)\end{array}$ & & & & & \\
\hline EXPsh_P & & & $\begin{array}{l}0.055 \\
(0.036)\end{array}$ & & & & \\
\hline EXPsh_P * WTO & & & $\begin{array}{l}-0.092 * * \\
(0.038)\end{array}$ & & & & \\
\hline PM & & & & $\begin{array}{l}0.301 * \\
(0.154)\end{array}$ & & & \\
\hline $\mathrm{PM} * \mathrm{WTO}$ & & & & $\begin{array}{l}-0.568^{* * *} \\
(0.195)\end{array}$ & & & \\
\hline FTAtradesh_11 & & & & & $\begin{array}{l}0.044^{*} \\
(0.023)\end{array}$ & $\begin{array}{l}0.044^{*} \\
(0.023)\end{array}$ & $\begin{array}{l}0.051 * * \\
(0.024)\end{array}$ \\
\hline FTAtradesh_11 * WTO_11 & & & & & $\begin{array}{l}-0.046 * * \\
(0.023)\end{array}$ & $\begin{array}{l}-0.040^{*} \\
(0.023)\end{array}$ & $\begin{array}{l}-0.050 * * \\
(0.024)\end{array}$ \\
\hline Year dummies & Yes & Yes & & & Yes & Yes & Yes \\
\hline Country fixed effects & & Yes & & & Yes & Yes & Yes \\
\hline R-squared & 0.997 & 0.961 & 0.999 & 0.999 & 0.968 & 0.970 & 0.966 \\
\hline Observations & 6,741 & 6,741 & 143 & 143 & 4,494 & 4,845 & 6,249 \\
\hline F-test for $b 1+b 2=0[p$-value $]$ & & & {$[0.034]$} & {$[0.027]$} & {$[0.814]$} & {$[0.511]$} & {$[0.816]$} \\
\hline
\end{tabular}

Notes: The dependent variable is $\log (r G D P / P O P)$. "X 11" refers to the lagged value of a variable X by one year. The following covariates are included in all of the regressions but not shown on the table to save space: $\log (r G D P / P O P) \_l 1, \log (I / G D P), \log (G / G D P), \log \left(g r \_P O P\right), W T O \_l 1$, and GSPexpsh_ll. The following time-invariant variables are also included in the OLS regressions: region dummies, legal origin dummies, a dummy for least developed countries, and a dummy for OPEC countries. These variables are not shown on the table to save space. FTAtradesh WTO measures a WTO member's FTA trade share with other WTO members in a given year (zero for a non-WTO member). FTAtradesh_nWTO measures a country's FTA trade share not between WTO members in a given year (i.e., when either this country or its FTA partners are outside the WTO). EXPsh_P is the share of exports that enjoy preferential tariffs. $P M$ is the calculated preference margin. These variables are explained in Section 4.1. Regression (5) drops microstates with average real GDP over 1960-2007 less than 10 million USD in constant 2005 price. Regression (6) drops the least developed countries (UNCTAD definition). Regression (7) drops the OPEC countries. Robust standard errors in parentheses. $* * * \mathrm{p}<0.01,{ }^{* *} \mathrm{p}<0.05,{ }^{*} \mathrm{p}<0.1$. 
Table 4: Endogeneity of FTAs

\begin{tabular}{|c|c|c|c|c|c|c|c|}
\hline & \multicolumn{3}{|c|}{ 2SLS (with country FEs) } & \multicolumn{4}{|c|}{ System GMM Method } \\
\hline & $(1)$ & $(2)$ & (3) & (4) & $(5)$ & $(6)$ & (7) \\
\hline & $\begin{array}{l}1^{\text {st }} \text { Stage: } \\
\text { FTAtradesh }\end{array}$ & $\begin{array}{l}1^{\text {st }} \text { Stage: WTO } \\
* \text { FTAtradesh }\end{array}$ & $2^{\text {nd }}$ Stage & Baseline & $\begin{array}{l}\text { Endo(FTA } \\
\& W T O)\end{array}$ & Endo(FTA) & $\begin{array}{l}\text { Endo(FTA) } \\
\text { \& Extra IVs }\end{array}$ \\
\hline FTAtradesh_l1 & & & $\begin{array}{l}0.226 * * * \\
(0.070)\end{array}$ & $\begin{array}{l}0.116 * * * \\
(0.035)\end{array}$ & $\begin{array}{l}0.094 * * * \\
(0.027)\end{array}$ & $\begin{array}{l}0.109 * * * \\
(0.028)\end{array}$ & $\begin{array}{l}0.106 * * * \\
(0.028)\end{array}$ \\
\hline FTAtradesh_11 *WTO_l1 & & & $\begin{array}{l}-0.151 * * * \\
(0.039)\end{array}$ & $\begin{array}{l}-0.103 * * \\
(0.041)\end{array}$ & $\begin{array}{l}-0.085 * * \\
(0.035)\end{array}$ & $\begin{array}{l}-0.104 * * * \\
(0.036)\end{array}$ & $\begin{array}{l}-0.099 * * * \\
(0.036)\end{array}$ \\
\hline $\log (\mathrm{rGDP} / \mathrm{POP}) \_11$ & $\begin{array}{l}0.030 * * * \\
(0.005)\end{array}$ & $\begin{array}{l}0.022 * * * \\
(0.005)\end{array}$ & $\begin{array}{l}0.960 * * * \\
(0.003)\end{array}$ & $\begin{array}{l}0.989 * * * \\
(0.010)\end{array}$ & $\begin{array}{l}0.986 * * * \\
(0.007)\end{array}$ & $\begin{array}{l}0.987 * * * \\
(0.007)\end{array}$ & $\begin{array}{l}0.986^{* * *} \\
(0.007)\end{array}$ \\
\hline $\log (\mathrm{I} / \mathrm{GDP})$ & $\begin{array}{l}-0.004 \\
(0.004)\end{array}$ & $\begin{array}{l}-0.002 \\
(0.004)\end{array}$ & $\begin{array}{l}0.017 * * * \\
(0.003)\end{array}$ & $\begin{array}{l}0.020^{*} \\
(0.011)\end{array}$ & $\begin{array}{l}0.022 * * \\
(0.009)\end{array}$ & $\begin{array}{l}0.021 * * \\
(0.009)\end{array}$ & $\begin{array}{l}0.021 * * \\
(0.009)\end{array}$ \\
\hline $\log (\mathrm{G} / \mathrm{GDP})$ & $\begin{array}{l}-0.009 \\
(0.006)\end{array}$ & $\begin{array}{l}-0.010^{*} \\
(0.006)\end{array}$ & $\begin{array}{l}-0.027 * * * \\
(0.004)\end{array}$ & $\begin{array}{l}-0.051 * * * \\
(0.014)\end{array}$ & $\begin{array}{l}-0.046^{* * * *} \\
(0.011)\end{array}$ & $\begin{array}{l}-0.048 * * * \\
(0.012)\end{array}$ & $\begin{array}{l}-0.047 * * * \\
(0.012)\end{array}$ \\
\hline $\log ($ gr_POP) & $\begin{array}{l}-0.008 * * * \\
(0.003)\end{array}$ & $\begin{array}{l}-0.008^{* * * *} \\
(0.003)\end{array}$ & $\begin{array}{l}-0.004 * * \\
(0.002)\end{array}$ & $\begin{array}{l}-0.009 * * \\
(0.004)\end{array}$ & $\begin{array}{l}-0.008 * * \\
(0.004)\end{array}$ & $\begin{array}{l}-0.008 * * \\
(0.004)\end{array}$ & $\begin{array}{l}-0.008 * * \\
(0.004)\end{array}$ \\
\hline WTO_11 & $\begin{array}{l}0.032 * * * \\
(0.008)\end{array}$ & $\begin{array}{l}0.011 \\
(0.008)\end{array}$ & $\begin{array}{l}0.004 \\
(0.005)\end{array}$ & $\begin{array}{l}0.011 \\
(0.011)\end{array}$ & $\begin{array}{l}0.007 \\
(0.009)\end{array}$ & $\begin{array}{l}0.013 \\
(0.010)\end{array}$ & $\begin{array}{l}0.012 \\
(0.010)\end{array}$ \\
\hline GSPexpsh_11 & $\begin{array}{l}-0.149 * * * \\
(0.008)\end{array}$ & $\begin{array}{l}-0.142 * * * \\
(0.007)\end{array}$ & $\begin{array}{l}0.018^{*} \\
(0.010)\end{array}$ & $\begin{array}{l}0.009 \\
(0.014)\end{array}$ & $\begin{array}{l}0.005 \\
(0.012)\end{array}$ & $\begin{array}{l}0.006 \\
(0.012)\end{array}$ & $\begin{array}{l}0.006 \\
(0.012)\end{array}$ \\
\hline Contagion_l1 & $\begin{array}{l}181.210 * * * \\
(18.350)\end{array}$ & $\begin{array}{l}91.121 * * * \\
(17.015)\end{array}$ & & & & & \\
\hline Contagion_11 * WTO_11 & $\begin{array}{l}9.897 * * * \\
(3.586)\end{array}$ & $\begin{array}{l}\text { 62.597*** } \\
(3.325)\end{array}$ & & & & & \\
\hline Observations & 6,741 & 6,741 & 6,741 & 6,675 & 6,675 & 6,675 & 6,675 \\
\hline F-statistics of excluded IVs & 58.32 & 212.74 & & & & & \\
\hline F-test for $b 1+b 2=0[p$-value $]$ & & & {$[0.170]$} & {$[0.505]$} & {$[0.640]$} & {$[0.807]$} & {$[0.720]$} \\
\hline Test for $1^{\text {st }}$ order $\mathrm{AC}$ [p-value] & & & & {$[0.000]$} & {$[0.000]$} & {$[0.000]$} & {$[0.000]$} \\
\hline Test for $2^{\text {nd }}$ order AC [p-value] & & & & {$[0.255]$} & {$[0.251]$} & {$[0.250]$} & {$[0.250]$} \\
\hline
\end{tabular}


Appendix 1: List of 177 counties and regions covered in the growth regressions

\begin{tabular}{|c|c|c|c|c|c|}
\hline Afghanistan & Central Afr. Rep. (1961) & Ghana (1960) & Lesotho (1961) & Panama (1998) & Suriname (1971) \\
\hline Albania (2001) & Chad (1961) & Greece (1960) & Liberia & Papua New Guinea (1975) & Swaziland (1971) \\
\hline Algeria (1961) & Chile (1960) & Grenada (1971) & Libya & Paraguay (1994) & Sweden (1960) \\
\hline Angola (1971) & China (2002) & Guatemala (1992) & Luxembourg (1960) & Peru (1960) & Switzerland (1960) \\
\hline Antigua \& Barbuda (1977) & Colombia (1976) & Guinea (1960) & Macao (1971) & Philippines (1973) & Syria \\
\hline Argentina (1962) & Comoros (1969) & Guinea-Bissau (1962) & Macedonia (2003) & Poland (1971) & Taiwan (2005) \\
\hline Australia (1960) & Congo, Dem. (1960) & Guyana (1971) & Madagascar (1961) & Portugal (1963) & Tajikistan \\
\hline Austria (1960) & Congo, Rep. (1961) & Haiti (1961) & Malawi (1965) & Qatar (1971) & Tanzania (1961) \\
\hline Azerbaijan & Costa Rica (1991) & Honduras (1994) & Malaysia (1960) & Romania (1972) & Thailand (1983) \\
\hline Bahamas (1971) & Cote D Ivoire (1961) & Hong Kong (1961) & Maldives (1971) & Russia & Togo (1961) \\
\hline Bahrain (1971) & Croatia (2001) & Hungary (1974) & Mali (1961) & Rwanda (1965) & Tonga (1971) \\
\hline Bangladesh (1973) & Cuba (1971) & Iceland (1964) & Malta (1973) & St. Kitts \& Nevis (2003) & Trinidad \& Tobago (1960) \\
\hline Barbados (1963) & Cyprus (1960) & India (1960) & Mauritania (1961) & St. Lucia (1977) & Tunisia (1962) \\
\hline Belgium (1960) & Czech Rep. (1994) & Indonesia (1961) & Mauritius (1960) & St. Vincent \& Gren. (1977) & Turkey (1960) \\
\hline Belize (1971) & Denmark (1960) & Iran & Mexico (1987) & Samoa & Turkmenistan \\
\hline Benin (1961) & Djibouti (1971) & Iraq & Moldova & Sao Tome \& Principe (1971) & Uganda (1960) \\
\hline Bermuda (1971) & Dominica (1977) & Ireland (1968) & Mongolia (1997) & Saudi Arabia (2006) & UAE (1971) \\
\hline Bhutan & Dominican Rep. (1960) & Israel (1960) & Morocco (1987) & Senegal (1961) & UK (1960) \\
\hline Bolivia (1991) & Ecuador (1996) & Italy (1960) & Mozambique (1962) & Serbia \& Montenegro & USA (1960) \\
\hline Bosnia \& Herzeg. & Egypt (1963) & Jamaica (1962) & Namibia (1967) & Seychelles (1970) & Uruguay (1960) \\
\hline Botswana (1970) & El Salvador (1991) & Japan (1960) & Nepal (2004) & Sierra Leone (1962) & Uzbekistan \\
\hline Brazil (1960) & Equ. Guinea (1963) & Jordan (2000) & Netherlands (1960) & Singapore (1961) & Vanuatu \\
\hline Brunei (1971) & Eritrea & Kazakhstan & New Zealand (1960) & Slovakia (1994) & Venezuela (1991) \\
\hline Bulgaria & Ethiopia & Kenya (1960) & Nicaragua (1960) & Slovenia (1995) & Vietnam (2007) \\
\hline Burkina Faso (1961) & Fiji (1961) & Kiribati (1971) & Niger (1961) & Solomon Islands (1971) & Yemen, Rep. (1990) \\
\hline Burundi (1964) & Finland (1960) & Korea, South (1967) & Nigeria (1960) & Somalia & Zambia (1960) \\
\hline Cambodia (1972) & France (1960) & Kuwait (1971) & Norway (1960) & South Africa (1960) & Zimbabwe (1960) \\
\hline Cameroon (1961) & Gabon (1961) & Kyrgyzstan (1999) & Oman (2001) & Spain (1964) & \\
\hline Canada (1960) & Gambia (1961) & Laos & Pakistan (1960) & Sri Lanka (1960) & \\
\hline Cape Verde (1962) & Germany, Fed. (1971) & Lebanon & Palau & Sudan & \\
\hline
\end{tabular}

Notes: This table lists the countries covered by the regressions in Table 2. De factor GATT/WTO entry years are in parentheses, except for the countries or regions that were still outside the WTO by 2007 (including those entered after 2007 such as Russia). For countries and regions that entered the GATT/WTO before July 1 of a year, the following year is taken as the entry year. 
Appendix 2: RTAs used to construct the RTA trade share variables (Total: 270)

\begin{tabular}{|c|c|c|c|}
\hline $\mathrm{ACM}$ & Czech-Israel & EFTA-Singapore & Pakistan-China \\
\hline $\mathrm{ACS}^{*}$ & Czech-Latvia & EFTA-Slovak & Pakistan-Sri Lanka* \\
\hline AFTA & Czech-Lithuania & EFTA-Slovenia & Pan-Arab Free Trade \\
\hline AMU & Czech-Slovak & EFTA-Turkey & Panama-El Salvador \\
\hline Albania- Moldova & Czech-Turkey & EFTA-West Bank & Panama-Singapore \\
\hline Albania-Bosnia \& Herzeg. & Dominica-Costa Rica & Egypt-Turkey* & Panama-Taiwan \\
\hline Albania-Macedonia & Dominica-El Salvador & El Salvador-Mexico & Poland-Faroe Islands \\
\hline Albania-Serbia Mont. & Dominica-Guatemala & Estonia-Faroe Islands & Poland-Israel \\
\hline Arab Free Trade Area & Dominica-Honduras & Estonia-Turkey & Poland-Latvia \\
\hline Armenia-Canada* & EAC* & Estonia-Ukraine & Poland-Lithuania \\
\hline Armenia-Cyprus & EAEC & Faroe Islands-Iceland & Poland-Turkey \\
\hline Armenia-Estonia & $\mathrm{EC}$ & Faroe Islands-Norway & Korea-Singapore \\
\hline Armenia-Kazakhstan & EC-Albania & Faroe Islands-Switzerland & Romania-Moldova \\
\hline Armenia-Moldova & EC-Algeria & $\mathrm{G} 3$ & SACU \\
\hline Armenia-Russian & EC-Andorra & $\mathrm{GCC}^{*}$ & SADC \\
\hline Armenia- Turkmenistan & EC-Bulgaria & GSTP* & SAFTA* \\
\hline Armenia- Ukraine & EC-Chile & Georgia-Armenia & SAPTA* \\
\hline BAFTA & EC-Croatia & Georgia-Azerbaijan & SPARTECA* \\
\hline Bangkok Agreement* & EC-Cyprus* & Georgia-Kazakhstan & Serbia Mont.-Bulgaria \\
\hline Bangkok Agreement-China* & EC-Czech & Georgia-Russia & Serbia-Mont.-Romania \\
\hline Belarus-Ukraine & EC-Egypt & Georgia-Turkmenistan & Singapore-Australia \\
\hline Bolivia-Chile & EC-Estonia & Georgia-Ukraine & Slovak-Estonia \\
\hline Bosnia \& Herzeg.-Serbia Mont. & EC-Macedonia & Guatemala-Mexico & Slovak-Israel \\
\hline Bulgaria-Albania & EC-Faroe Islands & Honduras-Mexico & Slovak-Latvia \\
\hline Bulgaria-Estonia & EC-Hungary & Hungary-Estonia & Slovak-Lithuania \\
\hline Bulgaria-Israel & EC-Iceland & Hungary-Israel & Slovak-Turkey \\
\hline Bulgaria-Latvia & EC-Israel & Hungary-Latvia & Slovenia-Bosnia \& Herzeg. \\
\hline Bulgaria-Lithuania & EC-Jordan & Hungary-Lithuania & Slovenia-Croatia \\
\hline Bulgaria-Macedonia & EC-Latvia & Hungary-Turkey & Slovenia-Estonia \\
\hline Bulgaria-Turkey & EC-Lebanon & IOR-ARC* & Slovenia-Israel \\
\hline Bhutan-India & EC-Lithuania & India-Afghanistan* & Slovenia-Latvia \\
\hline CACM & EC-Malta & India-Sri Lanka & Slovenia-Lithuania \\
\hline CACM-Chile & EC-Mexico & Japan-Malaysia & Slovenia-Macedonia \\
\hline CACM-Costa Rica & EC-Morocco & Japan-Mexico & Switzerland-Armenia \\
\hline CAFTA-Dominican Rep. & EC-Norway & Japan-Singapore & TRIPARTITE* \\
\hline CAN & EC-OCTs & Jordan-Singapore & Thailand- Australia \\
\hline CARICOM & EC-Poland & Kyrgyz-Armenia & Thailand- New Zealand \\
\hline CARICOM-Cuba & EC-Romania & Kyrgyz-Kazakhstan & Trans-Pacific SEP \\
\hline
\end{tabular}




\begin{tabular}{|c|c|c|c|}
\hline CARICOM-Bahamas & EC-Slovak & Kyrgyz-Moldova & Turkey-Syria \\
\hline CARICOM-Colombia* & EC-Slovenia & Kyrgyz-Russia & Turkey-Tunisia \\
\hline CARICOM-Costa Rica & EC-South Africa & Kyrgyz-Ukraine & Turkey-Bosnia \& Herzeg. \\
\hline $\mathrm{CBI}^{*}$ & EC-Switzerland & Kyrgyz-Uzbekistan & Turkey-Croatia \\
\hline CEFTA & EC-Syria & LAIA* & Turkey-Israel \\
\hline CEPGL & EC-Turkey & Laos-Thailand* & Turkey-Latvia \\
\hline CER & EC-Tunisia & MERCOSUR & Turkey-Lithuania \\
\hline CEZ & ECCAS & MERCOSUR-Bolivia & Turkey-Macedonia \\
\hline CIS & $\mathrm{ECO}^{*}$ & MERCOSUR-Chile & Turkey-Romania \\
\hline COMESA* & ECOWAS & MRU & Turkey-Slovenia \\
\hline Canada-Chile & EFTA & $\mathrm{MSG}^{*}$ & US-Canada \\
\hline Canada-Costa Rica & EFTA-Chile & Macedonia-Bosnia \& Herzeg. & US-Chile \\
\hline Canada-Israel & EFTA-Lebanon & Mexico-Nicaragua & US-Israel \\
\hline Chana-Burkina Faso & EFTA-Korea & Mexico-Uruguay & US-Jordan \\
\hline Chile-China & EFTA-Tunisia & Mexico-Bolivia & US-Singapore \\
\hline Chile-Colombia & EFTA-Bulgaria & Mexico-Costa Rica & Ukraine-Azerbaijan \\
\hline Chile-Costa Rica & EFTA-Croatia & Mexico-Israel & Ukraine-Kazakhstan \\
\hline Chile-Ecuador & EFTA-Czech & Moldova-Bulgaria & Ukraine-Macedonia \\
\hline Chile-El Salvador & EFTA-Estonia & Moldova-Croatia & Ukraine-Moldova \\
\hline Chile-Korea & EFTA-Finland & Moldova-Macedonia & Ukraine-Russia \\
\hline Chile-Mexico & EFTA-Hungary & Moldova-Serbia and Mont. & Ukraine-Tajikistan \\
\hline Chile-Venezuela & EFTA-Israel & Moldova- Bosnia \& Herzeg. & Ukraine -Turkmenistan \\
\hline China-Hong Kong & EFTA-Jordan & Morocco-Turkey & US-Albania \\
\hline China-Macao & EFTA-Latvia & NAFTA & US-Australia \\
\hline Colombia-Mexico & EFTA-Lithuania & New Zealand-Singapore & US-Bahrain \\
\hline Croatia-Macedonia & EFTA-Macedonia & OECS* & US-Vietnam \\
\hline Croatia-Serbia \& Mont. & EFTA-Mexico & PAFTA & US-Morocco \\
\hline Croatia- Bosnia \& Herzeg. & EFTA-Morocco & PATCRA & WAEMU* \\
\hline Croatia-Albania & EFTA-Poland & PICTA* & \\
\hline Czech-Estonia & EFTA-Romania & PTN* & \\
\hline
\end{tabular}

Data Sources: (1) WTO: http://www.WTO.org/english/tratop_e/region e/region e.htm. (2) WTO Archive, WTO, Geneva, Switzerland. (3) Frankel (1997). Regional Trading Blocs. Washington, DC: Institute for International Economics. (4) Schiff and Winters (2003). Regional Integration and Development. Washington, DC: Oxford University Press. (5) Foreign Trade Information System: http://www.sice.oas.org/agreements e.asp. (6) Tuck School Global Preferential Trade Agreement Database: http://www.dartmouth.edu/ tradedb/library.php. (7) McGill Preferential Trade Agreement Database: http://ptas.mcgill.ca/Pages\%20ptas/A-Z/A.htm

Notes: Trade agreements followed by a “*”are partial-scope agreements (PTAs). All others are either free trade areas or customs unions, which are referred to together as FTAs. Service agreements and accession agreements to existing agreements (e.g., EC) are not displayed or counted separately. An agreement that has entered into force before July 1 of a year is considered as effective in that year, and considered effective in the following year otherwise. Agreements between EC and some Central and Eastern European nations refer to the earlier FTAs before they entered the EU. 